\title{
LIFE CYCLE ASSESSMENT OF PALM OIL CLINKER AS A BINDER AND AGGREGATE REPLACEMENT IN CONCRETE
}

\section{SAZNIZAM SAZMEE SINOH*; ZAINAH IBRAHIM* and FARIDAH OTHMAN*}

\begin{abstract}
Palm oil clinker (POC) is a by-product derived from crude palm oil (CPO) production. Many studies have examined POC in concrete and it has often been stated as being environmentally sustainable. However, evidence to support these claims are not abundant in the literature. Therefore, this study aimed to assess the environmental impact of POC using a comparative, midpoints life cycle assessment approach based on 13 impact categories from ReCiPe2016. The use of POC as a binder replacement, fine aggregate and coarse aggregate was considered. Only production of cement, sand, gravel, POC and transportation were included in the system boundary. The construction, service and end-of-life phases were excluded. A volume of $1 \mathrm{~m}^{3}$ mortar or concrete with similar compressive strength was used as the functional unit. Life cycle inventory data was obtained from the literature, Malaysia Life Cycle Inventory Database (MY-LCID) and Ecoinvent database. Economic and mass allocation factors were calculated for POC. Calculations indicated that the use of POC in mortar and concrete showed reductions in all impact categories when economically allocated. When mass allocated, POC contributed minimally to all impact categories except 'Freshwater Eutrophication' and 'Human Toxicity'. Despite these drawbacks, results show that use of POC resulted in an overall improvement for the environmental sustainability.
\end{abstract}

Keywords: life cycle assessment, palm oil clinker, sustainable concrete, binder replacement, aggregate replacement, environment impact.

Received: 14 February 2020; Accepted: 7 June 2020; Published online: 7 October 2020.

\section{INTRODUCTION}

Oil palm (Elaeis guineensis) is a species of palm originating from West Africa which was brought into Malaya and planted commercially at Tennamaram Estate, Selangor, Malaya for the first time in 1917 and later became one of the country's key economic sectors (Nambiappan et al., 2018). A complex process transforms oil palm fruit into crude palm oil (CPO) which undergoes further refinement as cooking oil or as biodiesel (Hansen et al., 2014). Malaysia is the world's second largest producer of CPO, the largest exporter of $\mathrm{CPO}$ and the leading contributor for technical-based palm oil studies (Hansen et al., 2015). The production of CPO of this magnitude

\footnotetext{
Department of Civil Engineering,Universiti Malaya,

Jalan Universiti, 50603 Kuala Lumpur, Malaysia.

E-mail: zainah@um.edu.my
}

creates a proportionally large quantity of waste. This creates an opportunity for Malaysia to be the leading proponent for the use of this waste in the local construction industry.

Figure 1 shows a schematic diagram of the $\mathrm{CPO}$ production process and its by-products based on literature and on-site investigation. Palm oil mills utilise energy recovery by burning solid wastes from the production of CPO. This involves incinerating empty fruit bunches (EFB), oil palm shells (OPS) and mesocarp fibre (MF) in a boiler at more than $500^{\circ} \mathrm{C}$ to produce steam. This steam is used for electricity generation and sterilisation of fresh fruit bunches (FFB) in the CPO production process (Subramaniam et al., 2008). After incineration is complete, a grey, clumpy, hard and solid compound remains which is known as palm oil clinker (POC) (Ahmad and Nurazuwa, 2007). 


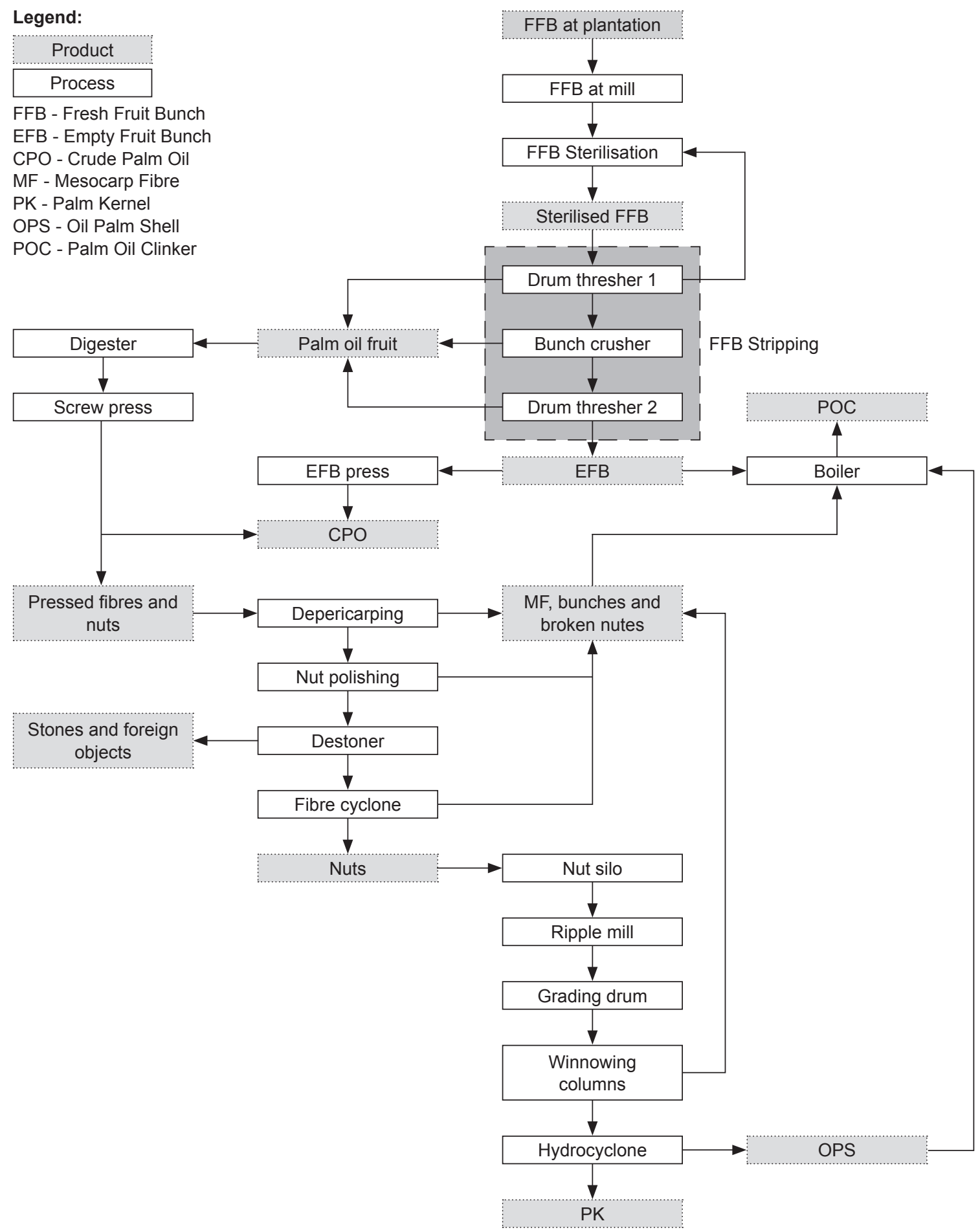

Figure 1. Production of crude palm oil (CPO) and its by-products.

POC is produced differently to another palm oil by-product (POBP) commonly utilised in concrete which is palm oil fuel ash (POFA). Fuel ash or fly ash is driven out of the boiler together with other flue gases and collected by particle filtration or electrostatic precipitators (Black, 2016). On the other hand, ash which settles towards the bottom of the boiler and fuses together is known as clinker (Sims and Brown, 1998). Thus, POC usually requires crushing and sizing before it can be used as an aggregate in concrete while POFA only requires homogenisation using a rotary pan mixer (Karim et al., 2018).

Conventionally, POC is used as a filler for mill roads or is disposed as waste (Subramaniam et al., 2008). However, fundamental principles of waste management dictate that disposal should be a last resort (Abdullah and Sulaiman, 2013). 
Thus, researchers have studied the use of POC as a construction material. Early work on POC have shown that it can be used in mortar and concrete as either a binder or aggregate replacement. However, most of these studies on POC only address its engineering performance, but not its environmental impact.

Palm oil has received considerable attention in the past 25 years among the academic community. An exponential increase in palm oil related publications was observed from 355 publications in 2004 to 1796 in 2013 (Hansen et al., 2015). Many of the studies that contributed towards this increase were from the use of $\mathrm{POBP}$ as a green construction material. In fact, POBP have a diverse range of novel applications (Hamada et al., 2018). For example, Alengaram et al. (2016) studied the use of OPS to improve the blast resistance of concrete. Apart from that, Mazlan et al. (2020) used cellulose nanocrystals extracted from EFB as a mortar admixture. These studies are just a handful of research showing the potential of POBP which were considered as waste products several decades earlier.

Research into the use of POBP in concrete started as early as the 1990s with the introduction of POFA as a pozzolanic material in concrete (Tay, 1990). Ahmad et al. (2007) found that the use of POC as coarse aggregate in concrete was able to produce compressive strengths which were satisfactory for use as structural members. Beginning in the 2010s, research into the use of POBP diversified with its use in concrete mixes to produce lightweight concrete (Alengaram et al., 2011) and to produce structural members (Mo et al., 2016).

Most of the studies for POBP in concrete were related to its physical and durability properties. Studies on the sustainability aspect of concrete containing POBP, specifically POC, were not abundant in the literature. For example, Kanadasan and Abdul Razak (2015a) reported the reduction in carbon emissions relative to POC content in concrete but no other impact categories were included in their environmental impact assessment. Kanadasan et al. (2015) reported the environmental impacts of POC concrete but was limited to carbon dioxide $\left(\mathrm{CO}_{2}\right)$ emissions and engineering environmental index (EEI) only. Aslam et al. (2016) mentioned the potential of concretes containing POC as a step closer to achieving sustainable development but did not perform any environmental assessment. Likewise, Ahmmad et al. (2017) discussed the feasibility of using POC in lightweight concrete but this was limited to engineering aspects and did not include environmental impacts. Yet, some studies did report the cost efficiency of using palm oil byproducts in concrete which showed that use of POC reduces the overall cost of the concrete and may be advantageous in terms of financial savings (Shafigh et al., 2014; Kanadasan and Abdul Razak, 2015a).
Technical, social, economic and environmental aspects associated with the use of POC as a construction material should be addressed in a balanced manner for academic research to contribute to the holistic sustainable development of both the palm oil and construction industries. Subsequently, systematic studies on the environmental performance of POC as a construction material were not abundant in the literature. Thus, the goal of this study was to evaluate the environmental impacts of incorporating $\mathrm{POC}$ as a binder or aggregate replacement. Life cycle assessment (LCA) was used as the framework for environmental impact assessment of POC. Using LCA provides a detailed and systematic analysis of the environmental impacts of concrete in a variety of impact categories which are lacking in other impact evaluation methods.

\section{LCA of Concrete}

The LCA is a systematic method to quantify the inputs and outputs associated with the manufacture of a product. Studies relating to LCA in the construction industry are fragmented due to the variety of case studies, functional units, system boundaries, material selection, geographic locations, construction processes, building design and building use (Abd Rashid and Yusoff, 2015). There are two types of LCA commonly used in the construction industry: (1) comprehensive building LCA (also known as whole building LCA) which assesses the environmental impact of a building over its life span; and (2) comparative LCA which compares the environmental impacts of construction materials. This study used the comparative LCA method in which the environmental impacts of conventional mortar and concrete were compared to their counterparts containing POC.

Investigation into the environmental impacts of concrete gained popularity in the 1990s as awareness of the environment started to take hold in the public mindset and the construction industry began shifting towards more sustainable practices (Nielsen and Glavind, 2007). Much attention has shifted to concrete since it is the most abundantly used construction material and its production alone represents approximately $6 \%-7 \%$ of all anthropogenic carbon dioxide (Akan et al., 2017). The term 'green' implies an environmental-friendly alternative to conventional concrete which often have reduced cement content, incorporate renewable or sustainable materials and possess reduced environmental impacts. Numerous studies have used LCA to systematically assess the environmental impacts of various materials in concrete such as recycled aggregate (Dobbelaere et al., 2016). Concrete incorporating POC also represents a green concrete which has been comprehensively studied in terms of its technical performance, but less so in terms of its environmental impact. 


\section{MATERIALS AND METHODOLOGY}

\section{Mix Design}

The mortar and concrete mix designs used in the study were obtained from the literature. Mortar mixes were obtained from Sumesh et al. (2018) and Kanadasan and Abdul Razak (2015b). Concrete mixes were obtained from Abutaha et al. (2016) and Mohd Hilton et al. (2008). These mixes are summarised in Table 1. The number in the mix designation indicates the percent replacement of either binder or aggregate. M- 0 denotes the reference mix for mortar and M-40 denotes a replacement of $40 \%$ binder with palm oil clinker powder (POCP). For C-0, C-100C and C-100F, cement content remained constant but with different ratios of sand, gravel, coarse POC and fine POC. Here, C- 0 was the reference mix for concrete. From Figure 2, compressive strengths at 28 days of the mortar mixes (M-0 and $\mathrm{M}-40)$ and concrete mixes (C-0, C-100C and C-100F) are shown. Although these mixes were designed for various purposes, they were selected to show that POC mixes can achieve comparable compressive strength with conventional mortar or concrete. This is also consistent with the functional unit used in the study.

TABLE 1. MIXED PROPORTIONS OF MORTAR, CONCRETE AND PALM OIL CLINKER

\begin{tabular}{lccccc}
\hline \multicolumn{1}{c}{ Mix } & Cement & $\begin{array}{c}\text { Water-to- } \\
\text { binder ratio }\end{array}$ & Sand & Gravel & $\begin{array}{c}\text { Palm oil } \\
\text { clinker }\end{array}$ \\
\hline $\mathrm{M}-0^{\mathrm{a}}$ & 550 & 0.32 & 1650 & 0 & 0 \\
$\mathrm{M}-40^{\mathrm{b}}$ & 520 & 0.29 & 1140 & 0 & $350^{\mathrm{e}}$ \\
$\mathrm{C}-0^{\mathrm{c}}$ & 420 & 0.53 & 760 & 1007 & 0 \\
${\mathrm{C}-100 \mathrm{C}^{\mathrm{d}}}$ & 420 & 0.55 & 621 & 0 & $729^{\mathrm{f}}$ \\
${\mathrm{C}-100 \mathrm{~F}^{\mathrm{c}}}^{\mathrm{f}}$ & 420 & 0.53 & 0 & 1007 & $614^{\mathrm{g}}$ \\
\hline
\end{tabular}

Note: All units in $\mathrm{kg} \mathrm{m}^{3}$

${ }^{\text {aS }}$ Umesh et al. (2018).

${ }^{\mathrm{b}}$ Kanadasan and Abdul Razak (2015b).

'Abutaha et al. (2016).

${ }^{\mathrm{d}}$ Mohd Hilton et al. (2008).

ePalm oil clinker powder.

${ }^{\mathrm{f}}$ Coarse palm oil clinker.

${ }^{8}$ Fine palm oil clinker.

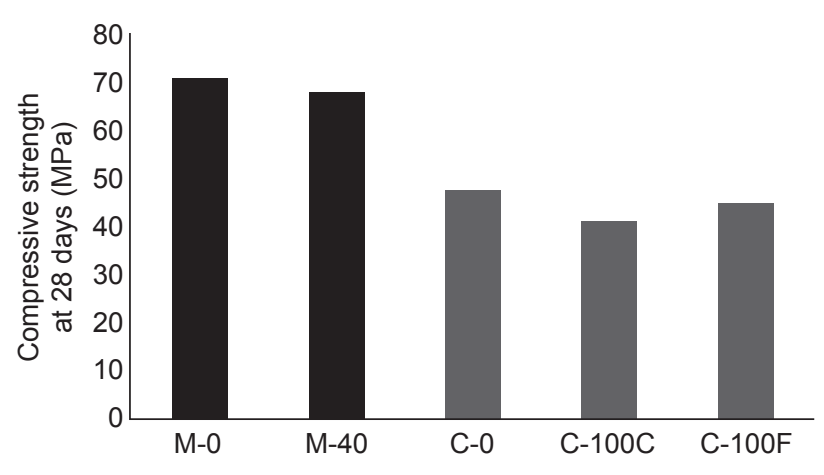

Figure 2. Compressive strength of mortar and concrete.

\section{LCA Framework}

The LCA in this study followed ISO 14040 (2006a) and ISO 14044 (2006b) which respectively describe the principles and framework of an LCA. These standard documents have been used as the standard framework for LCA for over 20 years. However, they do not specify the mechanics of the LCA such as methods for data collection which are left to the practitioner to decide. This allows LCA to be used for environmental impact assessment in different applications. As shown in Figure 3, an LCA is comprised of four stages: goal and scope definition, inventory analysis, impact assessment, and interpretation. In this study, the Results and Discussion section was used as the Impact Assessment and Interpretation phases of the LCA.

\section{Functional Unit}

The LCA requires a functional unit (FU) to be defined as a unit of reference between different LCA studies. It is necessary to define that all concrete fulfil the same functional requirements (Marinkovic et al., 2016). In other words, their mechanical properties and durability must be similar. It was desirable to use a FU which included strength and durability characteristics of the concrete which was employed in some studies (Van den Heede and De Belie, 2014). However, studies on the longterm durability properties of POC concrete are not abundant in the literature. Furthermore, it was assumed that exposure conditions were nonaggressive. Therefore, this study used a FU based on volume and compressive strength only. From Figure 2 , it was observed that the compressive strengths for mortar mixes were within the range of $68 \mathrm{MPa}$ to 71 $\mathrm{MPa}$. In addition, the concrete mixes were within the range of $41 \mathrm{MPa}$ to $47 \mathrm{MPa}$. Thus, the FU used in this study were as follows:

- Mortar mixes: $1 \mathrm{~m}^{3}$ with $70 \mathrm{MPa}$ compressive strength at 28 days.

- Concrete mixes: $1 \mathrm{~m}^{3}$ with $45 \mathrm{MPa}$ of compressive strength at 28 days.

\section{Goal and Scope Definition}

The system boundary of the LCA was defined based on the goal of the study which was to evaluate the environmental impacts of incorporating POC into cement mortar and concrete. The system boundary in this study included the production and transport of the following materials: cement, aggregate (coarse and fine) and POC (coarse, fine and powder). The concrete mixing process, transport to construction site, maintenance and demolition phases were excluded from the LCA. The effects of these phases may be excluded from an LCA if 
two compared products are in the same geographic location and fulfil the same role. Marinkovic et al. (2010) noted that to compare two different concrete types, the exposure conditions must be the same. Under this assumption, they concluded that the impact of construction, use and end-of-life phases were expected to be approximately equal. This study used similar assumptions to Marinkovic et al. (2010). Therefore, the resulting system boundary for the LCA is shown in Figure 4.

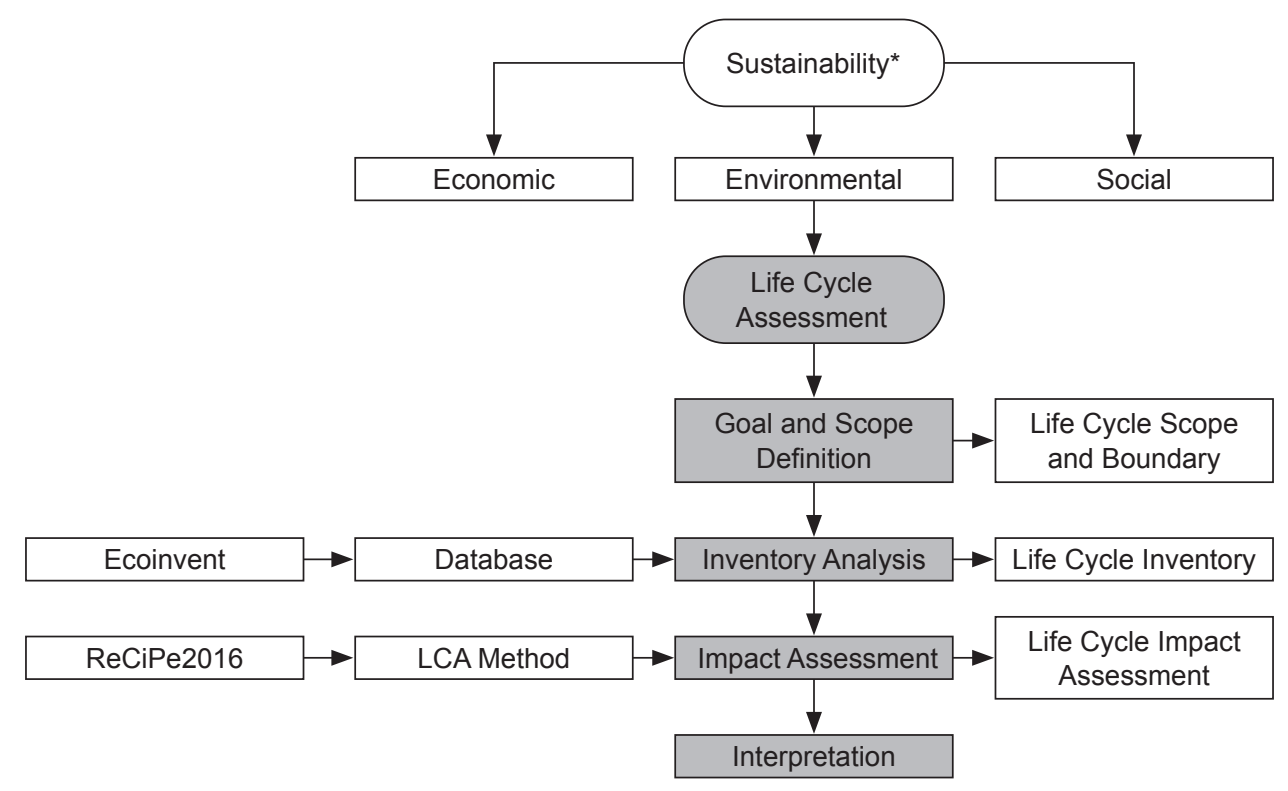

Note: *Definition of sustainability according to UNESCAP (2015).

Figure 3. Framework of the study.

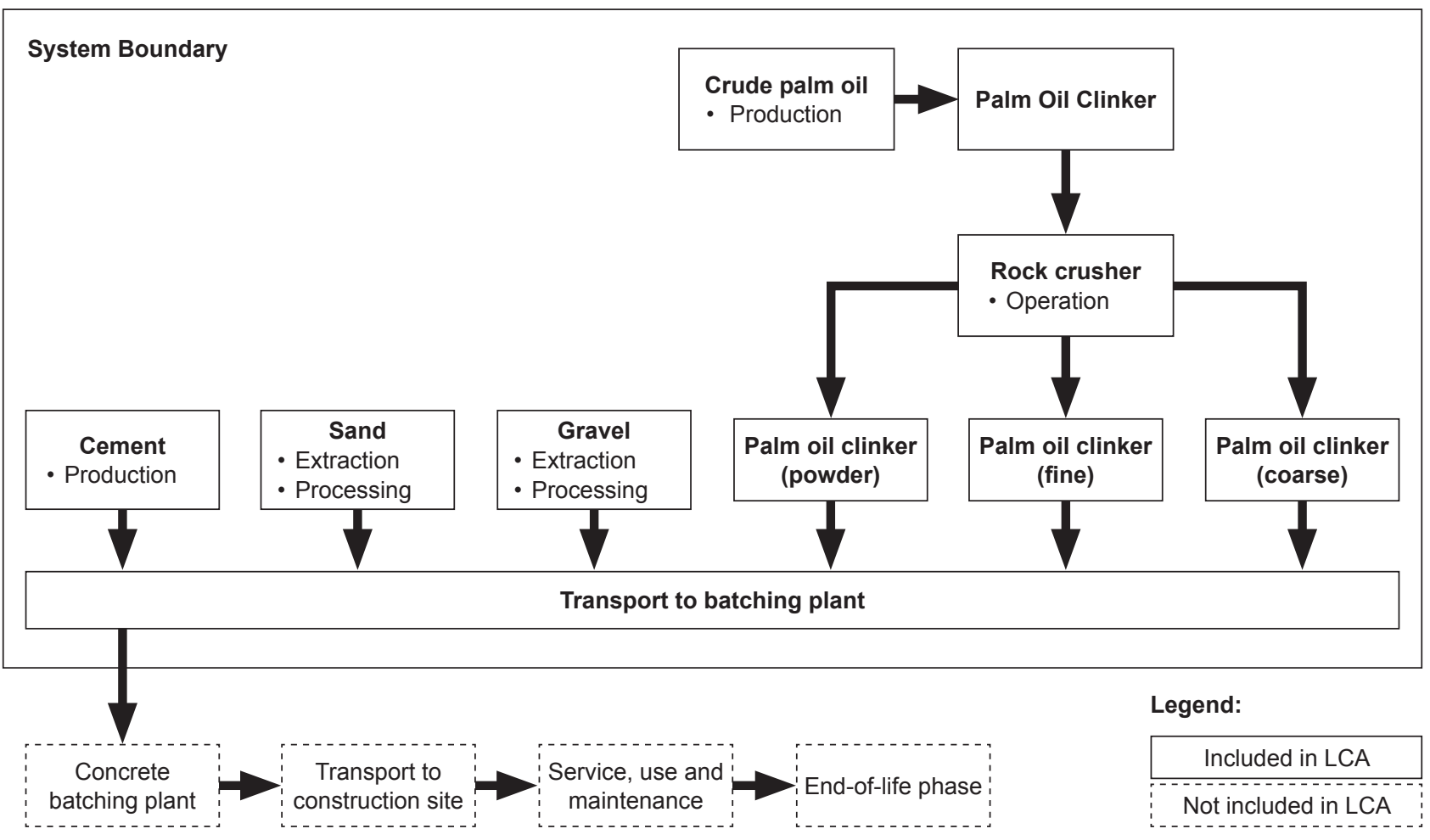

Figure 4. System boundary for the life cycle assessment (LCA) in this study. 


\section{Impact Assessment Methodology}

The impact assessment was carried out using the ReCiPe 2016 (hierarchist) framework which is a midpoints (i.e. problem) oriented approach (Huijbregts et al., 2016). The hierarchist perspective was selected due to its balance between shortand long-term damaging effects. This framework includes 13 midpoint impact categories which are described in Table 2. Midpoints are the links in the cause-effect chain (environmental mechanism) of an impact category to the endpoints, which is where characterisation factors are derived to reflect the relative significance of emissions. In other words, midpoints describe the point between the source of pollution and the resulting damage to either humans or the ecosystem. Midpoints are useful to identify emission targets and areas of specific environmental concern. On the other hand, endpoints have less certainty, but they are more relevant to decision support. However, determining cause-effect environmental impact relationships was a desirable outcome of this study as opposed to decision-support. Therefore, this study carried out the life cycle impact assessment using a midpointsoriented approach.

\section{Inventory Analysis}

Various sources were used to construct the life cycle inventory (LCI) used in this study. LCI data for production of cement, sand and gravel were obtained from the Malaysia Life Cycle Inventory Database (MY-LCID) to enhance the geographical representativeness of the LCA results and make more accurate conclusions within the Malaysian context (MY-LCID, 2020). The LCI data for sand and gravel were equal since these were considered to be produced from the same process (Marinkovic et al., 2010). On the other hand, LCI data for production of $\mathrm{CPO}$ and emissions from transportation were obtained from the Ecoinvent database (MartínezRocamora et al., 2016). The CPO dataset was geographically representative for Malaysia, but the transportation dataset was global. The Ecoinvent database was selected due to its integrity, usability and dedicated resources (Martínez-Rocamora et al., 2016). The crushing process for the POC clinker was based on the operation of a rock crusher from Landfield and Karra (2000). The crushing process was assumed to produce powder, coarse and fine POC and the energy required for all processes were considered to be the same (Marinkovic et al., 2010). Other studies have also used multiple LCI databases to supplement any data limitations (Onn et al., 2019).

A truncated inventory from the various materials in the study are shown in Table 3. Calculations were carried out using generic LCA tools, in this case Microsoft Excel. This method was selected to provide full control over the input data and calculations (Nemecek et al., 2010). It was also selected to provide simple integration with building information modelling (BIM) tools. BIM is a 3-dimensional (3D), parametric modelling software for construction (Anton and Diaz, 2014). BIM software can output information such as quantity of building materials directly to Microsoft Excel spreadsheets which may be readily used for LCA calculations (Shin and Cho, 2015).

\section{Transport Distances}

Transport distances were estimated using geographical information system (GIS) software using average road travel distance. A theoretical concrete construction site located in the centre of Kuala Lumpur was established. The average transport distances of concrete constituent materials to the construction site are shown in Table 4 . Transport distances were multiplied by a factor of two to represent the return journey of the lorry after transportation of materials. A locality map showing the location of the construction site in relation to material sources are shown in Figure 5. In addition to the consumption of fuel and emission of greenhouse gases, this study considered the impacts from production, maintenance and use of the lorries. The type of lorry considered for transportation of all materials was considered to be a 16-32 t lorry with EURO3 emissions standard.

\section{Allocation Factors}

Some processes produce more than one product. Thus, environmental impacts must be distributed or 'allocated' among the multiple products. In this case, the production of CPO produces various co-products in addition to POC. It is possible to consider POC as a waste since it is discarded by most palm oil mills. However, according to the European Union (2008) Directive 2008/98/EC it may also be classified as a useful co-product since it was used as a replacement for cement, sand and gravel in this study. This study used two common methods for allocation: (1) mass allocation and (2) economic allocation. Marinković et al. (2017) found that mass allocation resulted in unreasonably high environmental impacts for fly ash and opted to use economic allocation instead. Van den Heede and De Belie (2012) also recommended the use of economic allocation over mass allocation for cement-replacement materials. If mass allocation were used, the high allocated impacts would be a negative factor against their use in the construction industry. However, the use of mass allocation served as a form of sensitivity analysis and was included in the study. Therefore, the main method of allocation was by economic value and supplemented by mass allocation as sensitivity analysis. 
TABLE 2. OVERVIEW OF IMPACT CATEGORIES IN THE STUDY

\begin{tabular}{|c|c|c|c|}
\hline Impact category & Midpoint characterisation factor (CFm) & CFm abbrev. & Unit \\
\hline Climate change & Global warming potential & GWP & $\mathrm{kg} \mathrm{CO}$ eq. \\
\hline Ozone depletion & Ozone depletion potential & ODP & kg CFC-11 eq. \\
\hline Ionising radiation & Ionising radiation potential & IRP & kBq Co-60 eq. \\
\hline Fine particulate matter formation & Particulate matter formation potential & PMFP & $\mathrm{kg} \mathrm{PM} \mathrm{PM}_{2.5} \mathrm{eq}$ \\
\hline Photochemical oxidant formation & Photochemical oxidant formation potential & POFP & $\mathrm{kg} \mathrm{NO}$ eq. \\
\hline Terrestrial acidification & Terrestrial acidification potential & TAP & $\mathrm{kg} \mathrm{SO}{ }_{2}$ eq. \\
\hline Freshwater eutrophication & Freshwater eutrophication potential & FEP & kg P eq. \\
\hline Ecotoxicity & Ecotoxicity potential & ETP & $1,4-\mathrm{DCB}$ eq. \\
\hline Human toxicity & Human toxicity potential & HTP & 1,4-DCB eq. \\
\hline Water use & Water consumption potential & WCP & $\mathrm{m}^{3}$ water consumed \\
\hline Land use & Agricultural land occupation potential & LOP & $\mathrm{m}^{2} \mathrm{x}$ annual crop eq. \\
\hline Mineral resource scarcity & Surplus ore potential & SOP & kg Cu eq. \\
\hline Fossil resource scarcity & Fossil fuel potential & FFP & kg oil eq. \\
\hline
\end{tabular}

Note: Impact categories are based on the ReCiPe2016 methodology (Huijbregts et al., 2016).

Chemical abbreviations: $\mathrm{CO}_{2}$ - carbon dioxide; CFC - chlorofluorocarbon; Co-60 - cobalt-60; $\mathrm{PM}_{2.5}$ - particulate matter (less than 2.5 $\mu \mathrm{m}$ diameter); $\mathrm{NO}_{\mathrm{x}}$ - nitrogen oxides; $\mathrm{SO}_{2}$ - sulphur dioxide; $\mathrm{P}$ - phosphorous; 1,4-DCB - 1,4-Dichlorobenzene; $\mathrm{Cu}$ - copper.

TABLE 3. SELECTED EMISSIONS INVENTORY FOR MATERIALS IN THE STUDY

\begin{tabular}{|c|c|c|c|c|c|}
\hline Emissions to air & Cement $^{c}$ & Crude palm oil ${ }^{\mathrm{c}}$ & Sand/gravel ${ }^{c}$ & Crushing $^{\mathrm{d}}$ & Transport $^{\mathrm{e}}$ \\
\hline Ammonia $\left(\mathrm{NH}_{3}\right)$ & $4.57 \mathrm{E}-06$ & $9.36 \mathrm{E}-06$ & 3.887E-08 & $9.48 \mathrm{E}-09$ & $2.09 \mathrm{E}-06$ \\
\hline Carbon dioxide $\left(\mathrm{CO}_{2}\right)$ & $9.82 \mathrm{E}-01$ & 5.03E-02 & 2.87E-03 & $1.36 \mathrm{E}-05$ & 1.39E-01 \\
\hline Methane $\left(\mathrm{CH}_{4}\right)$ & $1.21 \mathrm{E}-03$ & 1.97E-08 & $6.73 \mathrm{E}-06$ & $4.46 \mathrm{E}-11$ & 3.72E-09 \\
\hline Nitrogen oxides $\left(\mathrm{NO}_{\mathrm{x}}\right)$ & $2.24 \mathrm{E}-03$ & $3.42 \mathrm{E}-04$ & $1.94 \mathrm{E}-05$ & $1.25 \mathrm{E}-07$ & $1.04 \mathrm{E}-03$ \\
\hline Nitrous oxide $\left(\mathrm{N}_{2} \mathrm{O}\right)$ & $4.03 \mathrm{E}-06$ & $1.80 \mathrm{E}-06$ & $3.16 \mathrm{E}-8$ & $5.98 \mathrm{E}-09$ & $1.60 \mathrm{E}-06$ \\
\hline Non-methane volatile organic compounds (NMVOC) & $2.91 \mathrm{E}-05$ & $5.02 \mathrm{E}-05$ & $1.57 \mathrm{E}-06$ & $2.75 \mathrm{E}-08$ & $1.05-\mathrm{E} 4$ \\
\hline Particulate matter (PM2.5) & $2.30 \mathrm{E}-05$ & $9.62 \mathrm{E}-09$ & $3.98 \mathrm{E}-07$ & $9.62 \mathrm{E}-09$ & $5.83 \mathrm{E}-05$ \\
\hline Phosphorus (P) & 5.97E-07 & $3.70 \mathrm{E}-05$ & $4.59 \mathrm{E}-08$ & $4.91 \mathrm{E}-10$ & 2.65E-07 \\
\hline \multicolumn{6}{|l|}{ Water Consumption $^{\mathrm{a}}$} \\
\hline Agriculture & - & $9.91 \mathrm{E}-02$ & - & - & - \\
\hline Industry & $1.88 \mathrm{E}+00$ & - & $1.44 \mathrm{E}-02$ & $2.36 \mathrm{E}-06$ & $1.70 \mathrm{E}-04$ \\
\hline \multicolumn{6}{|l|}{ Land Use Change $^{b}$} \\
\hline From primary forest & $5.68 \mathrm{E}-03$ & $4.84 \mathrm{E}-03$ & $1.64 \mathrm{E}-04$ & $5.63 \mathrm{E}-09$ & $2.99 \mathrm{E}-07$ \\
\hline \multicolumn{6}{|l|}{ Fossil Fuel Use } \\
\hline Crude oil & 7.03E-03 & 3.05E-02 & $3.85 \mathrm{E}-04$ & $1.16 \mathrm{E}-05$ & 5.12E-02 \\
\hline
\end{tabular}

Note: ${ }^{a}$ Total surface water and groundwater.

${ }^{\mathrm{b}}$ Land transformation.

'Units for emissions of cement, crude palm oil, sand and gravel are in $\mathrm{kg}$ of emissions per $\mathrm{kg}$ of material.

${ }^{\mathrm{d}}$ Units for emissions of crushing are in $\mathrm{kg}$ of emissions per $\mathrm{kg}$ of material crushed.

eUnits for emissions of transport are in $\mathrm{kg}$ of emissions per tonne $\mathrm{x} \mathrm{km}$ of material transported.

TABLE 4. TRANSPORT DISTANCES OF MATERIALS

\begin{tabular}{|c|c|c|c|c|}
\hline \multirow{2}{*}{ Material } & \multirow{2}{*}{ Origin } & \multirow{2}{*}{ Destination } & \multicolumn{2}{|c|}{ Distance (km) } \\
\hline & & & Scenario $1^{\mathrm{a}}$ & Scenario $2^{b}$ \\
\hline Cement & Cement plant & Concrete batching plant & $70 \times 2=140$ & $100 \times 2=200$ \\
\hline Sand and gravel & Quarry & Concrete batching plant & $50 \times 2=100$ & $100 \times 2=200$ \\
\hline Palm oil clinker & Palm oil mill & Concrete batching plant & $110 \times 2=220$ & $100 \times 2=200$ \\
\hline
\end{tabular}

Note: aScenario based on estimated average transport distances.

${ }^{\mathrm{b}}$ Scenario assuming equal transport distances. 


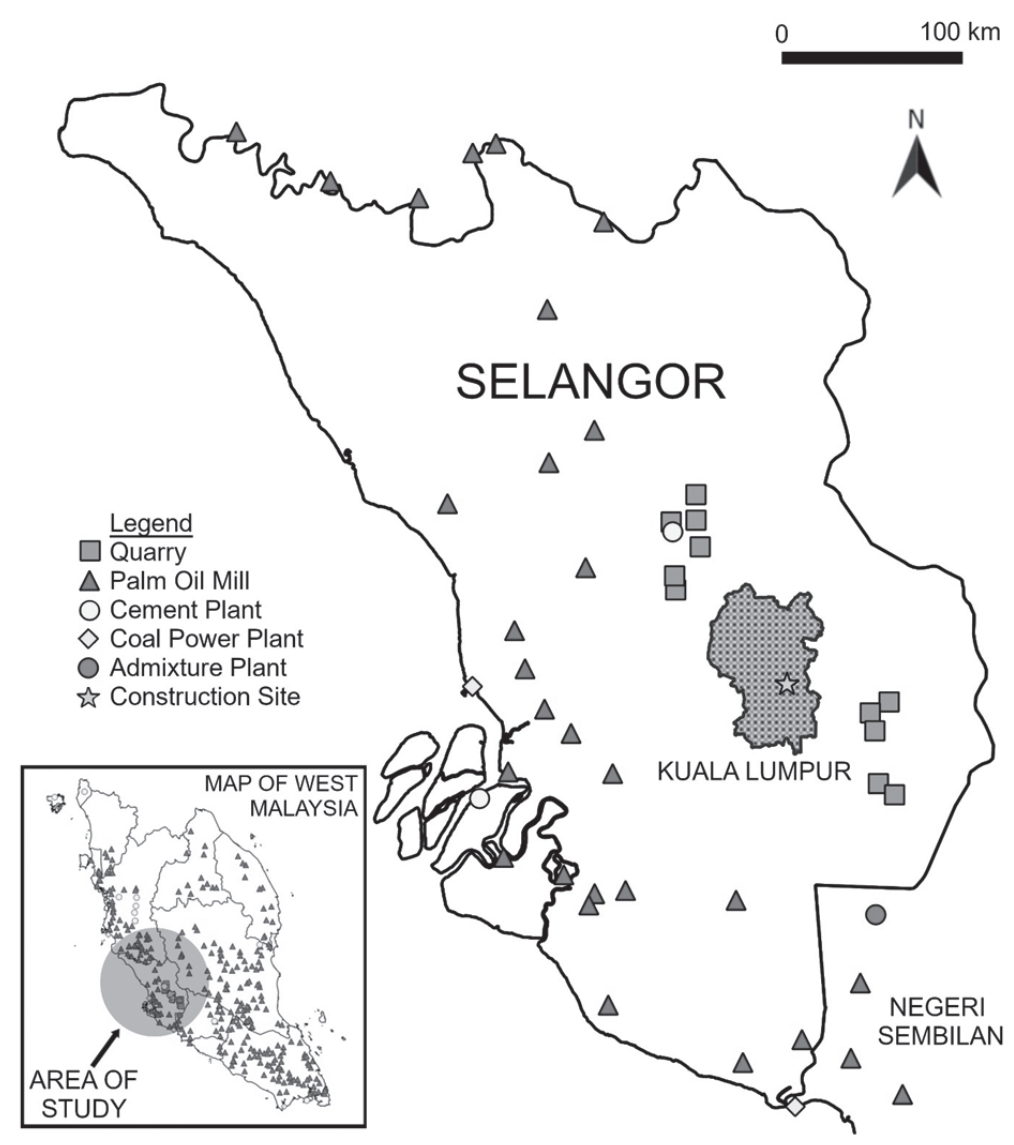

Figure 5. Locations of palm oil mills, cement plants, quarries and admixture plants located near the theoretical construction site in Kuala Lumpur.

Figure 6 shows the product system for production of $\mathrm{CPO}$ and its co-products. FFB from the oil palm plantation is processed at the oil palm mill to produce CPO, PK, OPS, MF and EFB. In addition, OPS and MF are fed into the on-site boiler to produce steam for the $\mathrm{CPO}$ production process. POC is the residue from the boiler furnace. This study allocated environmental impacts between CPO, PK, EFB and POC. This is because OPS and MF are the main source of fuel for the on-site boiler (Subramaniam et al., 2008). As such, these materials are rarely available outside the oil palm mill (Aghamohammadi et al., 2016). Moreover, they are intermediate materials to POC. Thus, OPS and MF may not be considered useful co-products to CPO. Though some mills may use EFB as fuel in their boilers, most are returned to the plantations for mulching thereby replenishing some nutrients of the soil (Chiew and Shimada, 2013). Also, PK contains residual oil and is put through additional processes to extract palm kernel oil (Subramaniam et al., 2008). Therefore, EFB and PK may be considered as useful co-products to CPO.

The economic allocation factor, $\mathrm{C}_{\mathrm{e}}$ was calculated according to Equation (1). On the other hand, the mass allocation factor, $C_{m}$ was given by Equation
(2). Both equations were defined by Chen et al. (2010) in their study on the LCA of green concretes. Ringgit Malaysia (RM) is the cost per unit material and $m$ is the mass of material produced during its production process. Kanadasan and Abdul Razak (2015a) estimated the cost factor for POC as RM $20 \mathrm{t}^{-1}$. Salleh (2018) reported the cost of EFB as RM 295.64 $\mathrm{t}^{-1}$. In 2015, the average price of CPO and PK were reported as RM $2153.50 \mathrm{t}^{-1}$ and RM 1527.50 $\mathrm{t}^{-1}$ respectively (MPOB, 2015). In 2015, RM fluctuated between RM 3.80 and RM 4.35 per US Dollar (USD) (Quadry et al., 2017). To avoid variations due to the high instability of the RM against the USD in 2015, prices were stated in terms of RM. Subramaniam et al. (2008) reported that for every $1 \mathrm{t}$ of CPO produced, there are $0.41 \mathrm{t}$ of PK, $1.17 \mathrm{t}$ of EFB and $0.02 \mathrm{t}$ of POC produced. Thus, the allocation factors included in the study were calculated as shown in Table 5.

$$
C_{e}=\frac{(\mathrm{RM} \times m)_{\text {by-product }}}{(\mathrm{RM} \times m)_{\text {main-product }}+(\mathrm{RM} \times m)_{\text {total-by-products }}}
$$

Equation (1)

$$
C_{m}=\frac{m_{\text {by-product }}}{m_{\text {main-product }}+m_{\text {total-by-products }}} \quad \text { Equation (2) }
$$




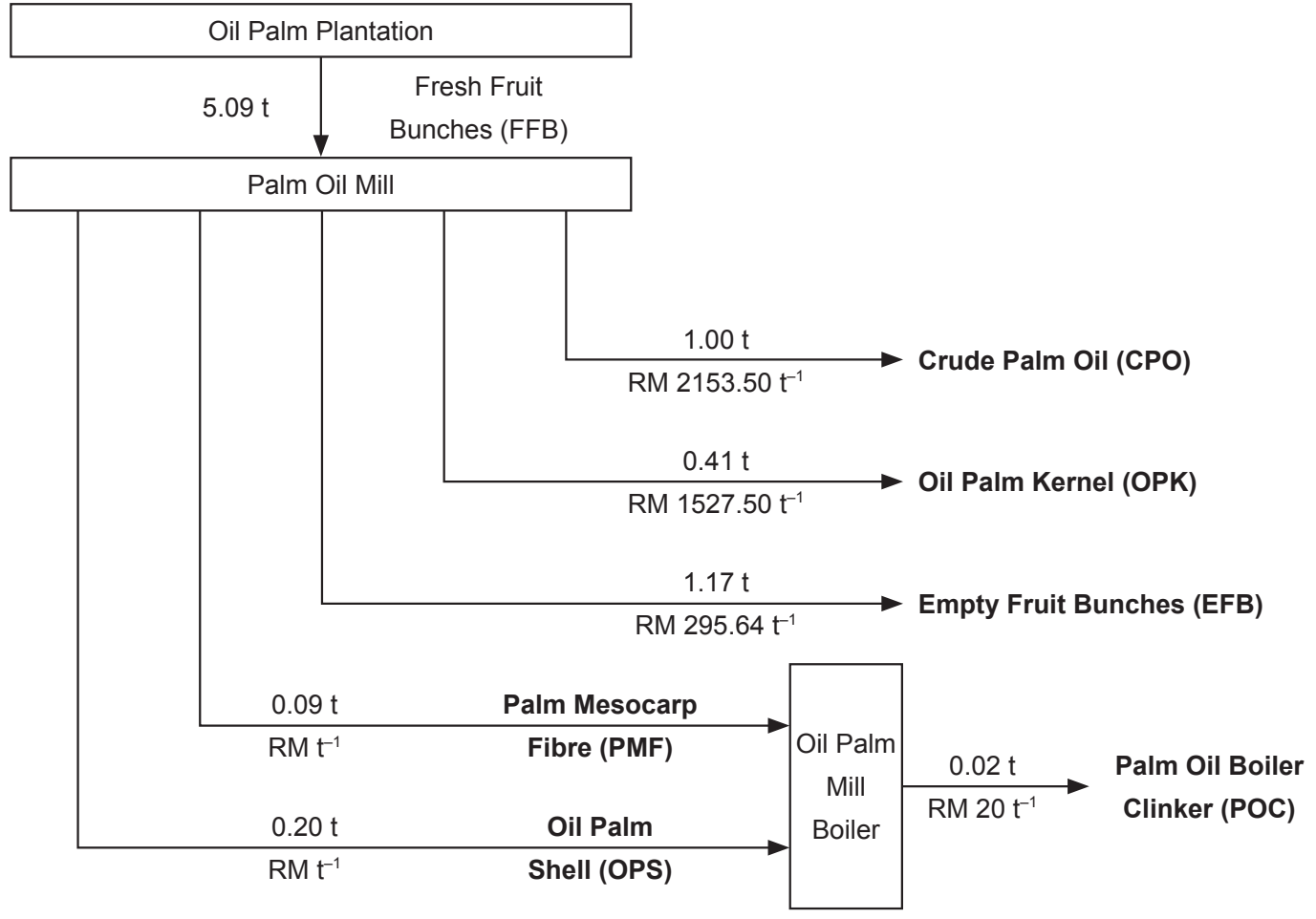

Figure 6. Product system for crude palm oil (CPO) and its co-products.

TABLE 5. ALLOCATION FACTORS BASED ON MASS AND ECONOMIC VALUES

\begin{tabular}{|c|c|c|c|c|}
\hline Product & $\begin{array}{l}\text { Mass produced } \\
(t)\end{array}$ & $\begin{array}{l}\text { Market price } \\
\left(\mathrm{RM} \mathrm{t}^{-1}\right)\end{array}$ & $\begin{array}{c}\text { Allocation by } \\
\text { mass value } \\
(\%)\end{array}$ & $\begin{array}{c}\text { Allocation by } \\
\text { economic value } \\
(\%)\end{array}$ \\
\hline Crude palm oil (CPO) & 1.00 & 2153.50 & 38.46 & 68.89 \\
\hline Oil palm kernel (PK) & 0.41 & 1527.50 & 15.77 & 20.03 \\
\hline Empty fruit bunches (EFB) & 1.17 & 295.64 & 45.00 & 11.06 \\
\hline Palm oil boiler clinker (POC) & 0.02 & 20.00 & 0.77 & 0.0128 \\
\hline Total & 2.60 & 3996.64 & 100.00 & 100.00 \\
\hline
\end{tabular}

\section{Land Use Scenarios}

The total planted area for oil palm in Malaysia reached 5.9 million hectares in 2019 which was approximately $18 \%$ of the country's total land area (MPOB, 2020). Oil palm plantations in Malaysia are primarily established on state land which consists mostly of degraded forest and are characterised by low carbon stocks (Hashim et al., 2018). Despite the clearing of forest for oil palm cultivation, Malaysia still manages to maintain more than $50 \%$ of forest cover (Hamid and Rahman, 2016). Before oil palms are planted, the degraded forest is cleared, and the remaining biomass is left to be broken down by litter-feeding invertebrates. Thus, nutrients from forest biomass are returned to the soil and enrich it for future cultivation. The time period required for complete decomposition of this biomass is assumed to be 25 years (Germer and Sauerborn, 2008).
This study used a similar methodology to Hansen et al. (2014) in which environmental impacts of land conversion from forest to plantation were allocated to the first generation of plantation use. Since oil palm plantations are replanted every 25 years, then only the plantations established in the past 25 years were considered to contribute to land use change impacts (Kongsager and Reenberg, 2012). Hansen et al. (2014) reported that approximately $30 \%$ of all oil palm plantations were first generation plantations established within 25 years. Therefore, this study multiplied the land use change (LUC) factor for POC by a factor of 0.3 . It must be noted that the ReCiPe2016 methodology used in this study focuses on the relative biological species loss due to LUC (Huijbregts et al., 2016). The methodology does not include emission of greenhouse gases due to decomposition of cleared forest biomass. 


\section{RESULTS AND DISCUSSION}

\section{Material Impacts}

This section is part of the LCA Impact Assessment and Interpretation phases. Table 6 shows results for the 13 impact categories considered in the study when POC was economically allocated with values in brackets indicating the impacts when POC was mass allocated. As per the FU used in the study, these impact values are for the production of $1 \mathrm{~m}^{3}$ of mortar or concrete respectively. The results in Table 6 are not inclusive of impacts from transportation of materials. From these impact values, Table 7 was created to show the percent change of POC mixes relative to their conventional mortar or concrete mixes. The mixes containing POC were compared to their respective conventional mixes within each impact category. For example, in the Global Warming Potential (GWP) impact category, the total emissions of M-40 is $6 \%$ lesser relative to $\mathrm{M}-0$ and the emissions of C-100C is $1 \%$ lesser compared to C- 0 .

From Table 7, the use of economically allocated POC as a powder, coarse aggregate and fine aggregate showed reductions in all impact categories. When mass allocated, POC shows reductions in the majority of impact categories. However, some categories showed significant increase compared to the reference mixes. Particularly, the high impacts in the Freshwater Eutrophication (FEP) impact category of all POC mixes may be attributed to fertiliser application during oil palm cultivation. FEP in ReCiPe2016 is mainly influenced by phosphorous (P).

Malaysia possesses 2.5 million hectares of peat which is approximately $7 \%$ of the total land area of the country (Rahman et al., 2014). An estimated $13 \%$ of oil palm plantations are located on peat soils in Malaysia (Hashim et al., 2017). Peat soil has been reported to be low in various nutrients such as $\mathrm{P}$ and application of $\mathrm{P}$ fertiliser is desirable to sustain optimal agricultural yields (Mutert et al. 1999). Thus, $P$ from the fertiliser may leach into nearby water bodies thereby influencing FEP. Hashim et al. (2017) also reported P runoff during oil palm cultivation as a significant contributor to eutrophication.

Another impact category with high contribution from POC is Human Toxicity (HTP). ReCiPe2016 uses 1,4-dichlorobenzene (1,4-DCB) and nickel (Ni) as the reference substances used in calculation of HTP. Since both MY-LCID and Ecoinvent lack data on 1,4-DCB emissions, then $\mathrm{Ni}$ was used as the main reference substance for calculation of HTP in this study. Ni occurs naturally in the soil which is accumulated in the biomass of oil palm fruit (Ooi et al., 2014). Zarcinas et al. (2004) found that $\mathrm{Ni}$ concentrations among fresh weight Malaysian food crops was highest among oil palm seed pulp. In addition, Said et al. (2016) demonstrated good potential for recovery of $\mathrm{Ni}$ from POFA which suggests that a good amount of $\mathrm{Ni}$ is contained within oil palm biomass. The burning of this biomass releases $\mathrm{Ni}$ into the atmosphere which poses carcinogenic risk to human health (Zambelli and Ciurli, 2013). Furthermore, operation and maintenance of oil palm plantations are supported by the use of heavy vehicles to transport biomass around the mill which may contribute to $\mathrm{Ni}$ emissions (Subramaniam et al., 2010).

\section{Contribution Analysis}

For each of the mixes in the study, the contribution of each material towards the total environmental impact are represented graphically using horizontal bar charts in Figures 7, 8 and 9. Contribution analysis reveals which material contributes the most towards a particular impact category.

Figures 7 to 9 show that in almost all impact categories, the material with the most dominant environmental impacts is cement. This is consistent with findings from previous literature where Braga et al. (2017) found that cement was the main governing factor for the environmental impact of concrete. In all mixes, economically allocated POC in all forms (i.e. powder, coarse and fine) contributed a relatively small percentage (less than $1 \%$ ) to the total environmental impact in all impact categories. When mass allocated, POC in all forms contributed a minority of the percentage to the total environmental impact in all but a few impact categories. Figures $7 c$, $7 d$ and $7 e$ show that mass allocated POC contributes highly to FEP and HTP.

POC is a product from the agricultural industry but contributed minimally to the 'Water Use' impact category. Agricultural products require water to produce biomass (Safitri et al., 2018). However, multiple studies have found that rainwater was sufficient to satisfy oil palm growth with minimal need for irrigation (Muhammad-Muaz and Marlia, 2014; Suttayakul et al., 2016; Safitri et al., 2018; Subramaniam and Hashim, 2018). On the other hand, the processing of sand requires a significant amount of water for washing and sizing (Grbes, 2015). Cement was the highest contributor to the 'Water Use' impact category. This is due to the energy intensive processes involved in cement production for which the water demand for energy generation is high (Hosseinian and Nezamoleslami, 2018).

POC also contributes minimally to the 'Land Use' impact category. Oil palm was found to be more sustainable compared to other crops such as soyabean, rapeseed or corn (De Vries et al., 2010). In fact, oil palm cultivation may encourage forest reversion and reduce carbon emissions due to oil 
palm plantation sequestration being higher than other crops (Sayer et al., 2012; Villoria et al., 2013). The high output of oil palm plantations reduces the need for excessive transformation of land (Barcelos et al., 2015). This explained the low contribution of POC towards the Land Use impact category despite being an agricultural product. Cement is also the highest contributor to this category. The high impact of cement may be attributed to construction and operation of cement factories which negatively affects the surrounding vegetation and water bodies (Dalil et al., 2017). Besides that, extraction of mineral aggregates such as sand and gravel have relatively high impacts compared to POC due to the negative impacts of quarries on the surrounding landscape (Allacker et al., 2014).

TABLE 6. MIDPOINT ENVIRONMENTAL IMPACTS OF MATERIALS

\begin{tabular}{|c|c|c|c|c|c|c|}
\hline Impact category & M-0 & M-40 & C-0 & C-100C & C-100F & Units \\
\hline Climate change & 569 & $536(537)$ & 436 & $432(433)$ & $434(434)$ & $\mathrm{kg} \mathrm{CO}_{2}$ eq. \\
\hline Ozone depletion & $2.50 \mathrm{E}-05$ & 2.35E-05 (2.35E-05) & $1.92 \mathrm{E}-05$ & 1.89E-05 (1.90E-05) & 1.90E-05 (1.91E-05) & kg CFC-11 eq. \\
\hline Ionising radiation & 4.30E-03 & 3.72E-03 (3.72E-03) & $3.72 \mathrm{E}-03$ & 2.75E-03 (2.76E-03) & 3.08E-03 (3.09E-03) & kBq Co-60 eq. \\
\hline $\begin{array}{l}\text { Fine particulate matter } \\
\text { formation }\end{array}$ & 0.529 & $0.499(0.499)$ & 0.406 & $0.401(0.401)$ & $0.403(0.403)$ & $\mathrm{kg} \mathrm{PM}_{2.5}$ eq. \\
\hline $\begin{array}{l}\text { Photochemical oxidant } \\
\text { formation }\end{array}$ & 1.270 & $1.192(1.193)$ & 0.979 & $0.957(0.959)$ & $0.965(0.966)$ & $\mathrm{kg} \mathrm{NO}$ eq. \\
\hline Terrestrial acidification & 1.756 & $1.655(1.656)$ & 1.348 & $1.333(1.335)$ & $1.338(1.339)$ & $\mathrm{kg} \mathrm{SO}$ eq. \\
\hline $\begin{array}{l}\text { Freshwater } \\
\text { eutrophication }\end{array}$ & $1.33 \mathrm{E}-04$ & 1.20E-04 (1.53E-04) & 1.09E-04 & 9.33E-05 (1.61E-04) & 9.90E-05 (1.56E-04) & kg P eq. \\
\hline Ecotoxicity & $6.67 \mathrm{E}-04$ & 6.29E-04 (9.43E-04) & $5.12 \mathrm{E}-04$ & 5.07E-04 (9.46E-04) & 5.09E-04 (9.00E-04) & 1,4-DCB eq. \\
\hline Human toxicity & $1.78 \mathrm{E}-04$ & 2.37E-04 (3.01E-04) & $1.83 \mathrm{E}-04$ & $1.36 \mathrm{E}-04(4.12 \mathrm{E}-04)$ & 1.67E-04 (3.69E-04) & 1,4-DCB eq. \\
\hline Water use & 1062.58 & 998.57 (998.68) & 818.74 & $802.21(802.45)$ & 807.78 (807.98) & $\begin{array}{l}\mathrm{m}^{3} \text { water } \\
\text { consumed }\end{array}$ \\
\hline Land use & 124.75 & $115.41(115.88)$ & 98.32 & $91.42(92.40)$ & $93.75(94.57)$ & $\begin{array}{l}\mathrm{m}^{2} \mathrm{x} \text { annual } \\
\text { crop eq. }\end{array}$ \\
\hline $\begin{array}{l}\text { Mineral resource } \\
\text { scarcity }\end{array}$ & 0.844 & $0.789(0.794)$ & 0.654 & $0.632(0.642)$ & $0.640(0.648)$ & kg Cu eq. \\
\hline Fossil resource scarcity & 47.00 & $44.15(44.32)$ & 36.29 & $35.49(35.83)$ & $35.78(36.07)$ & kg oil eq. \\
\hline
\end{tabular}

Note: Emissions shown are for production of $1 \mathrm{~m}^{3}$ of mortar or concrete.

Values not within brackets are results for economically allocated palm oil clinker (POC).

Values enclosed within brackets are results for mass allocated POC.

TABLE 7. PERCENT CHANGE IN RELATION TO REFERENCE MIXES

\begin{tabular}{|c|c|c|c|c|c|c|}
\hline \multirow{2}{*}{ Impact category } & \multicolumn{3}{|c|}{ Economic allocation } & \multicolumn{3}{|c|}{ Mass allocation } \\
\hline & $\mathrm{M}-40^{\mathrm{a}}(\%)$ & $\mathrm{C}-100 \mathrm{C}^{\mathrm{b}}(\%)$ & $\mathrm{C}-100 \mathrm{~F}^{\mathrm{b}}(\%)$ & $M-40^{a}(\%)$ & $C-100 C^{b}(\%)$ & $\mathrm{C}-100 \mathrm{~F}^{\mathrm{b}}(\%)$ \\
\hline Climate change & -6 & -1 & -1 & -6 & -1 & 0 \\
\hline Ozone depletion & -6 & -2 & -1 & -6 & -1 & -1 \\
\hline Ionising radiation & -14 & -26 & -17 & -14 & -26 & -17 \\
\hline Fine particulate matter formation & -6 & -1 & -1 & -6 & -1 & -1 \\
\hline Photochemical oxidant formation & -6 & -2 & -2 & -6 & -2 & -1 \\
\hline Terrestrial acidification & -6 & -1 & -1 & -6 & -1 & -1 \\
\hline Freshwater eutrophication & -10 & -15 & -10 & 15 & 47 & 42 \\
\hline Ecotoxicity & -6 & -1 & -1 & 12 & 46 & 39 \\
\hline Human toxicity & -6 & -2 & -1 & -6 & -2 & -1 \\
\hline Water use & -7 & -7 & -5 & -7 & -6 & -4 \\
\hline Land use & -6 & -3 & -2 & -6 & -2 & -1 \\
\hline Mineral resource scarcity & -6 & -2 & -1 & -6 & -1 & -1 \\
\hline Fossil resource scarcity & -6 & -1 & -1 & -6 & -1 & 0 \\
\hline
\end{tabular}

Note: Underlined values show increased impacts compared to reference mixes.

apercent change in relation to $\mathrm{M}-0$.

bercent change in relation to $\mathrm{C}-0$. 


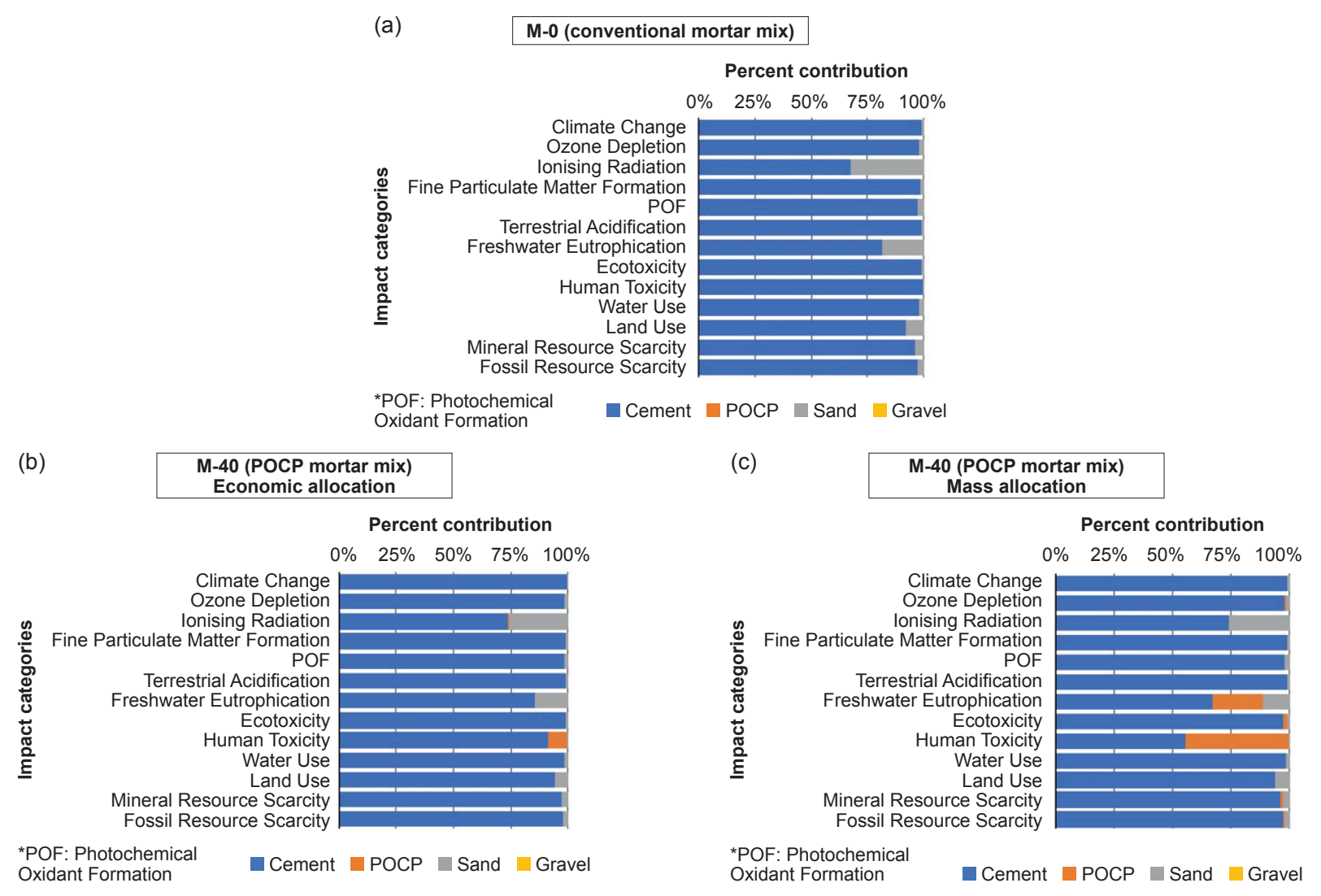

Figure 7. Contribution analysis for (a) cement mortar, (b) economically allocated palm oil clinker powder (POCP) mortar and (c) mass allocated (POCP) mortar.

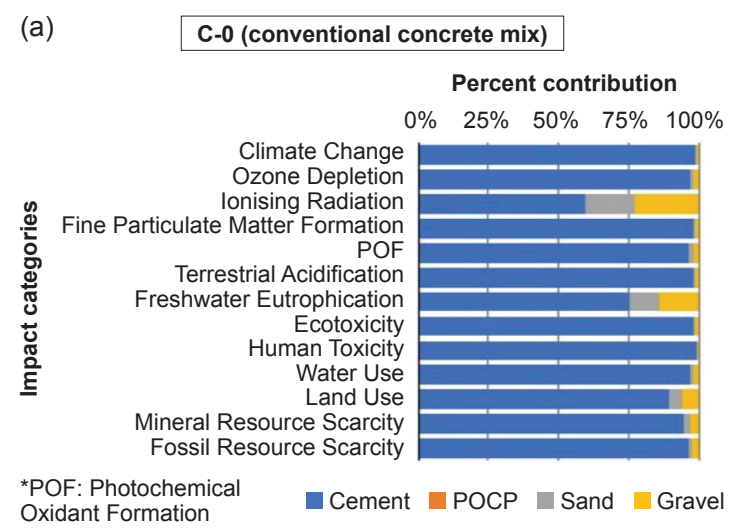

(b) C-100C (Coarse POC concrete mix)

Percent contribution

$\begin{array}{lllll}0 \% & 25 \% & 50 \% & 75 \% & 100 \%\end{array}$

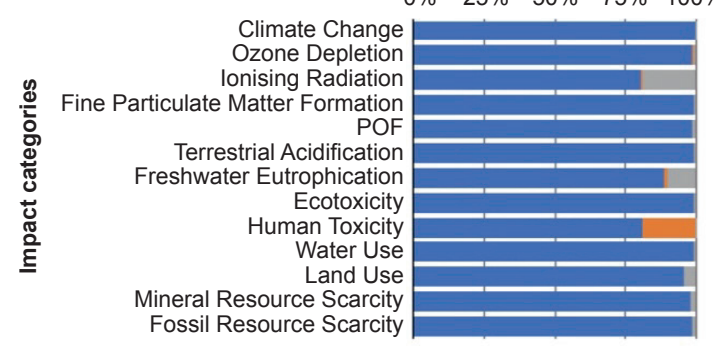

*POF: Photochemical

Oxidant Formation

¿ Cement $\square$ POCP Sand Gravel (c)

C-100C (coarse POC concrete mix) Mass allocation

Percent contribution

$\begin{array}{lllll}0 \% & 25 \% & 50 \% & 75 \% & 100 \%\end{array}$

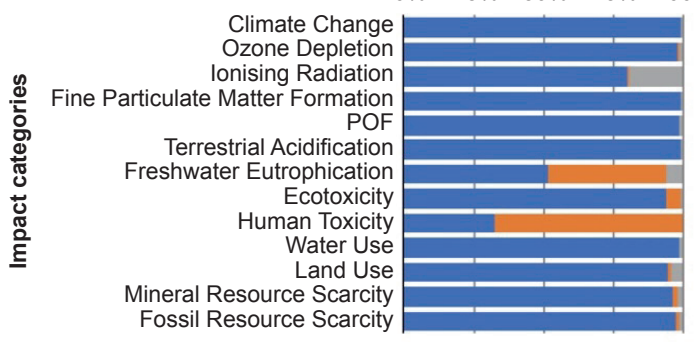

*POF: Photochemical

Oxidant Formation

Figure 8. Contribution analysis for (a) conventional concrete, (b) economically allocated coarse palm oil clinker (POC) concrete and (c) mass allocated coarse POC concrete. 
(a)

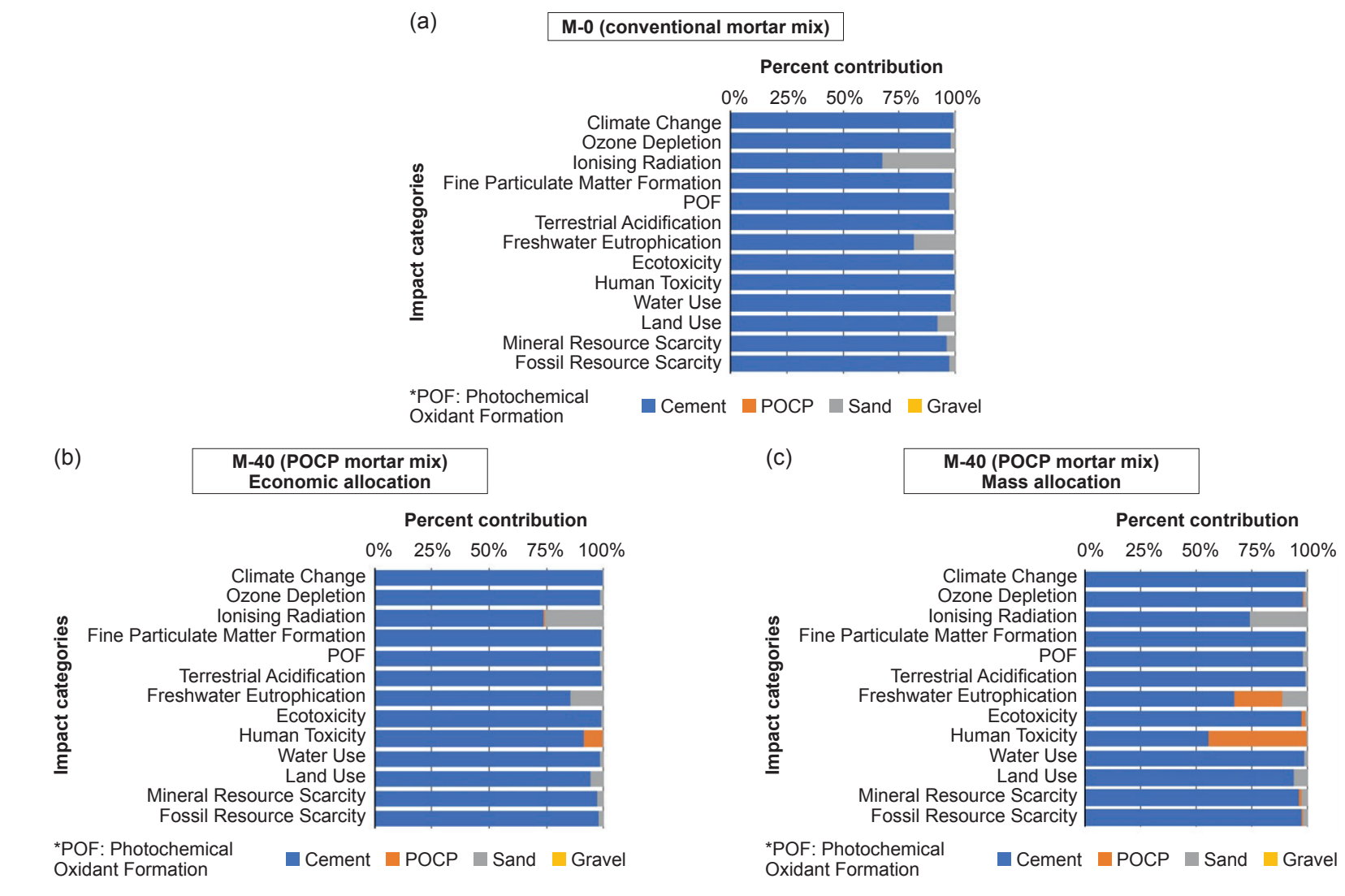

Figure 9. Contribution analysis for (a) conventional concrete, (b) economically allocated fine palm oil clinker (POC) concrete and (c) mass allocated fine POC concrete.

\section{Transport Emissions}

Table 8 shows the percent change in emissions of POC mixes compared to reference mixes. The percent change for a particular mix was equal across all impact categories. In Scenario 1, transportation emissions of POC mixes were higher compared to reference mixes. Emissions for $\mathrm{M}-40$ were approximately $9 \%$ higher compared to $\mathrm{M}-0$ in all impact categories. For concrete mixes, transportation emissions for C-100C and C-100F were higher than C-0 in all impact categories by approximately $19 \%$ and 25\% respectively. The increased emissions for POC mixes in this scenario may be explained by the increased average transport distance from the palm oil mill to the concrete construction site.

On the other hand, in Scenario 2, transportation emissions of POC mixes were lower than those of reference mixes. Emissions for M-40 were approximately $8 \%$ lower compared to M-0 in all impact categories. For concrete mixes, transportation emissions for C-100C and C-100F were lower than $\mathrm{C}-0$ in all impact categories by approximately $19 \%$ and $6 \%$ respectively. This reduction may be attributed to the reduced combined weight of all materials required for POC mixes. For example, the combined weight of cement and sand (per unit volume of concrete) for $\mathrm{M}-0$ is $2200 \mathrm{~kg} \mathrm{~m}^{-3}$ while that of cement, sand and POC for $\mathrm{M}-40$ is $2010 \mathrm{~kg} \mathrm{~m}^{-3}$. Since the transport distances were equal for all materials in this scenario, then the emissions values were influenced only by the combined weight of all materials of the mix. In this case, the reduced total weight of POC mixes was an advantage since it reduced transportation emissions. This was a similar advantage reported for lightweight concrete (Shafigh et al., 2014).

\section{Comparison with Other Studies}

It was useful to compare the results of normal concrete in this study with the literature. The impact values from the climate change impact category for normal concrete mixes were used as the main point of comparison. Specifically, the GWP of which is expressed in the unit kilograms of carbon dioxide equivalent $\left(\mathrm{kg} \mathrm{CO}_{2}\right.$ eq.). The GWP for various normal concrete mixes in the literature and their corresponding compressive strength are shown in Table 9 (Marinkovic et al., 2010; Tosic et al., 2015; Kim et al., 2016; Tait and Cheung; 2016, Braga et al., 2017; Mohammadi and South, 2017; Ahmad et al., 2017; Kurda et al., 2018). The Z-score was calculated for the GWP value of mix C-0 in this study (GWP $=436 \mathrm{~kg} \mathrm{CO}_{2}$ eq.) and compared to the GWP values of similar concrete mixes in the literature (mean $=366.38$, standard deviation $=52.87$ ). Based on Shiffler (1988), this Z-score $(Z=1.32)$ was well below the threshold $(Z=2.47)$ and was not considered as an outlier. The 
results show that GWP for C-0 was 1.03 standard deviations away from the mean and was not an abnormal data point. This is an evidence to suggest that the results of this study are consistent with the literature.

Figure 10 shows a correlation plot between cement content and GWP value for which the correlation coefficient was calculated. The results show that cement content was strongly positively correlated to GWP value $\left(R^{2}=0.72\right)$. Cohen (1992) suggested the following levels for measuring effect size of correlations: $\mathrm{R}^{2}=0.01$ is a small effect size; $\mathrm{R}^{2}=0.09$ is a medium effect size; and $\mathrm{R}^{2}=0.25$ is a large effect size. This further supported findings from previous literature that cement was the main governing material for environmental impact of concrete (Braga et al., 2017).

Kanadasan and Razak (2015a) reported that the carbon emissions for concrete where aggregate was

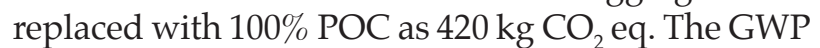
for mixes $\mathrm{C}-100 \mathrm{C}$ and $\mathrm{C}-100 \mathrm{~F}$ are within the range of $432-434 \mathrm{~kg} \mathrm{CO}$ eq. for both allocation methods. Therefore, this further indicates evidence that the results of this study are consistent with those obtained from the literature.

\section{Implications and Recommendations}

The results of the study provided evidence to support the claim that POC is an environmentalfriendly building material. The results for mass allocated POC represented a sensitivity analysis on the significant effect of POC when its environmental impacts were scaled up. For example, the increased impacts in FEP and HTP should not be ignored.

Apart from that, the predicted increased future yield of oil palm would mean a proportionately increased amount of oil-palm-related waste which would need to be properly managed or utilised (Murphy, 2014). The use of this waste in the construction industry would avoid the negative environmental impacts arising from their disposal.

In addition, the use of POC to replace gravel and sand as aggregates in the construction industry may decrease demand for extraction of mineralbased materials such as cement, gravel and sand from earth's lithosphere (Estanqueiro et al., 2016). Thus, the local construction industry's reliance on these materials are gradually diminished which leads to reduced damage to the surrounding landscape as well as subsequent problems that arise from it (Veraart, 2018). However, care must be taken to expand oil palm plantations in a sustainable manner. For example, careful management of fertiliser application should be practised to reduce damage to the ecosystem and, subsequently, human health (Darras et al., 2019). This is to prevent further increase of the environmental impacts of POC to the point where it is no longer a viable alternative to natural aggregates. Increasing yield of oil palm should go beyond simply increasing fertiliser inputs. Methods such as gene modification may produce higher yields with minimal negative environmental impact (Barcelos et al., 2015).

TABLE 8. PERCENT CHANGE IN TRANSPORTATION EMISSIONS

\begin{tabular}{|c|c|c|c|c|c|c|}
\hline \multirow[b]{2}{*}{ Impact category } & \multicolumn{3}{|c|}{ Scenario 1} & \multicolumn{3}{|c|}{ Scenario 2} \\
\hline & $\begin{array}{c}M-40^{a} \\
(\%)\end{array}$ & $\begin{array}{c}\mathrm{C}-100 \mathrm{C}^{\mathrm{b}} \\
(\%)\end{array}$ & $\begin{array}{c}\mathrm{C}-100 \mathrm{~F}^{\mathrm{b}} \\
(\%)\end{array}$ & $\begin{array}{c}M-40^{a} \\
(\%)\end{array}$ & $\begin{array}{c}C-100 C^{b} \\
(\%)\end{array}$ & $\begin{array}{c}\mathrm{C}-100 \mathrm{~F}^{\mathrm{b}} \\
(\%)\end{array}$ \\
\hline All impact categories & 9.01 & 19.44 & 25.09 & -8.64 & -19.07 & -6.68 \\
\hline
\end{tabular}

Note: The percent change in emissions is equal for all impact categories.

aPercent change in relation to $\mathrm{M}-0$.

${ }^{b}$ Percent change in relation to $\mathrm{C}-0$.

TABLE 9. SUMMARY OF NORMAL CONCRETE RESULTS FROM THE LITERATURE

\begin{tabular}{|c|c|c|c|}
\hline Reference & $\begin{array}{l}\text { Cement content } \\
\left(\mathrm{kg} \mathrm{m}^{-3}\right)\end{array}$ & $\begin{array}{c}\text { Compressive strength } \\
\text { (MPa) }\end{array}$ & $\begin{array}{l}\text { GWP value per } \mathrm{m}^{3} \text { concrete } \\
\left(\mathrm{kg} \mathrm{CO} \mathrm{CO}_{2} \text { eq.) }\right.\end{array}$ \\
\hline Marinkovic et al. (2010) & 315 & 39.2 & 307 \\
\hline Tosic et al. (2015) & 384 & 41.5 & 340 \\
\hline Kim et al. (2016) & 400 & 40 & 450 \\
\hline Tait and Cheung (2016) & 380 & $32-40$ & 339 \\
\hline Braga et al. (2017) & 350 & $30-37$ & 317 \\
\hline Mohammadi and South (2017) & 380 & 50 & 379 \\
\hline Ahmad et al. (2017) & 420 & 35 & 437 \\
\hline Kurda et al. (2018) & 350 & 55.8 & 362 \\
\hline Mean & 372.38 & 43.58 & 366.38 \\
\hline Standard deviation & 32.90 & 7.75 & 52.87 \\
\hline
\end{tabular}




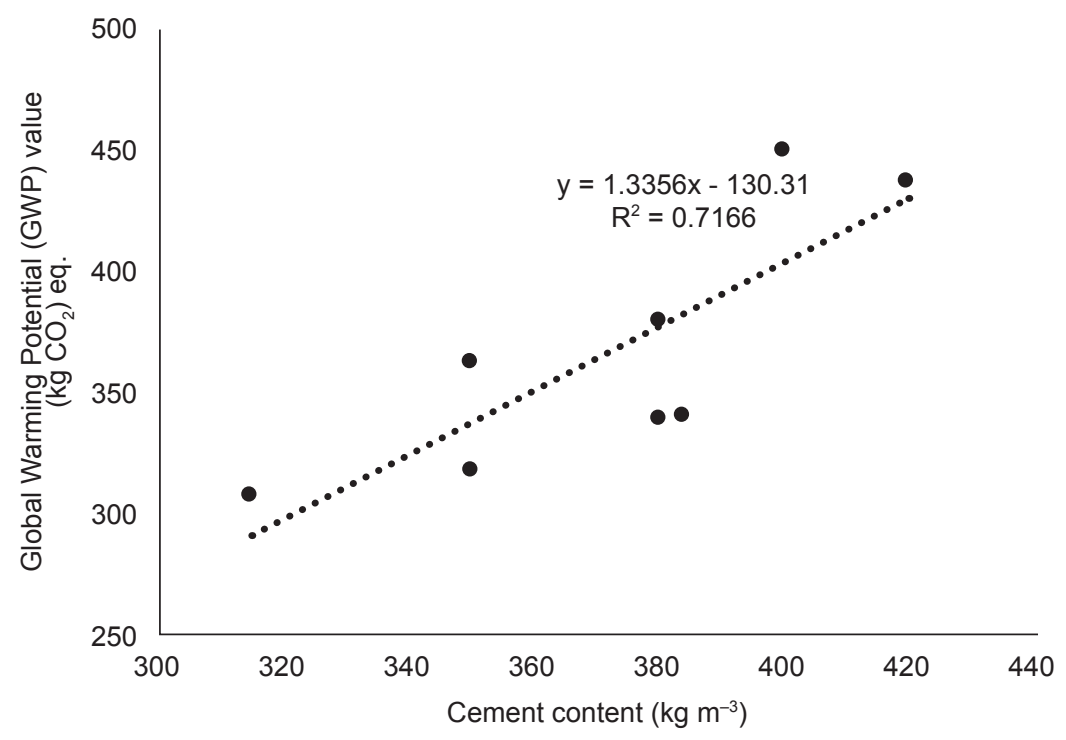

Figure 10. Correlation plot for cement content and Global Warming Potential (GWP) value.

Other than that, Braga et al. (2017) found that increasing the strength of the concrete does not necessarily increase environmental impacts. Cement represents approximately $6 \%-7 \%$ of all anthropogenic carbon dioxide (Akan et al., 2017). Thus, it is important to reduce cement content by substitution or use less of it to achieve similar engineering properties. The reduced cement may be substituted with suitable alternatives such as POCP. The reduction in compressive strength was not directly proportional to POCP content. Therefore, it may be possible to increase the proportion of POCP without significant decrease in compressive strength for mortar mixes.

Furthermore, some palm oil mills were reported to capture the emissions from palm oil mill effluent digestion (Subramaniam et al., 2008). This could further reduce the impact of POC in the Climate Change impact category. However, the capture of methane from palm oil mill effluent was not reflected in the Ecoinvent or MY-LCID databases. Future studies could consider this technique in their LCA to further reduce values of the climate change impact category.

Besides that, the mortar and concrete mixes in the study did not contain any fly ash which were reported to increase strength and durability of concrete containing POC (Ahmad et al., 2007). Thus, future studies could attempt to study the environmental impact of fly ash in concrete incorporating POC. Inclusion of fly ash into POC concrete could further decrease environmental impacts as reported by Marinkovic et al. (2016) for recycled aggregate concrete.

Finally, the FU selected for this study did not include durability characteristics of the concrete. This could be included in the FU if more studies on the durability of POC concrete were available such as chloride penetration and carbonation coefficient. Thus, a future study could be undertaken to establish an equivalent functional unit for POC concrete similar to work by Dobbelaere et al. (2016) for recycled aggregate concrete. Such a study would improve the accuracy of future LCA on POC concrete.

\section{CONCLUSION}

When economically allocated, the use of POC as a powder, coarse aggregate and fine aggregate in mortar or concrete had reduced impacts in all categories. Contribution analysis showed that POC contributed less than $1 \%$ of the total environmental impact in all impact categories when economically allocated. Cement was shown to be the material which contributed the most towards the total environmental impacts in all mixes.

When mass allocated, only the FEP and HTP impact categories showed significant increase in impact values. Reductions were observed in the majority of impact categories for mass allocation. Despite this, POC contributed minimally to the total impact in most categories.

For transport emissions, when transport distances were estimated based on GIS software, transport of POC showed increased impacts. This was due to the higher transport distance for POC compared to cement, sand or gravel. On the other hand, when transport distances of all materials were equal, then impacts of mixes with POC showed decreased impacts. This was explained by the lower total weight per unit volume of mixes containing POC. 
The GWP of normal concrete in this study was compared with similar mixes in the literature. Results show that the GWP of normal concrete for this study did not exceed the threshold to classify it as an outlier, indicating the results of this study were consistent with the literature. In addition, there was a strong positive correlation between cement content versus GWP value for the compared mixes in the literature.

Overall, the use of POC in concrete was shown to be beneficial for directly reducing the embodied environmental impacts of mortar and concrete. However, the allocation method strongly influenced the magnitude of the results. Thus, care must be taken to select a proper allocation method, preferably one which does not rely on physical properties.

In addition, the indirect benefits of using POC extend towards both the construction and agricultural industries. For example, the use of POC as a building material would avoid the negative environmental impacts arising from its disposal. It may also spur growth in the agricultural industry due to demand for its many useful co-products. In addition, it could reduce the demand on sand and gravel for use as aggregates in concrete, alleviating the exploitation of these materials from the natural system. Therefore, the use of POC as a construction material is recommended especially for countries with high CPO production such as Malaysia, Indonesia and Thailand. However, the long-term durability properties of structural members made with POC should be thoroughly explored.

\section{ACKNOWLEDGEMENT}

The authors highly appreciate the financial support by the Universiti Malaya Research Grant Project No. GPF003A-2019, GPF010A-2019 and the Universiti Malaya Academic Fellowship Scheme. We are most grateful and would like to thank the reviewers for their valuable suggestions, which led to a substantial improvement of this article.

\section{REFERENCES}

Abd Rashid, A F and Yusoff, S (2015). A review of life cycle assessment method for building industry. Renewable and Sustainable Energy Reviews, 45: 244248.

Abdullah, N and Sulaiman, F (2013). The oil palm wastes in Malaysia. Biomass Now - Sustainable Growth and Use. IntechOpen. p. 75-100. https://www. intechopen.com/books/ biomass-now-sustainablegrowth-and-use/ the-oil-palm-wastes-in-malaysia, accessed on 6 February 2020.
Abutaha, F; Abdul Razak, H and Kanadasan, J (2016). Effect of palm oil clinker (POC) aggregates on fresh and hardened properties of concrete. Construction and Building Materials, 112: 416-423.

Aghamohammadi, N; Reginald, S; Shamiri, A; Zinatizadeh, A; Wong, L and Nik Sulaiman, N (2016). An investigation of sustainable power generation from oil palm biomass: A case study in Sarawak. Sustainability, 8(5): 416.

Ahmad, M H and Nurazuwa, M N (2007). Physical properties of local palm oil clinker and fly ash. Paper presented at the $1^{\text {st }}$ Engineering Conference on Energy and Environment. 27-28 December 2007, Kuching, Sarawak.

Ahmad, M H; Sofian, M and Nurazuwa, M N (2007). Mechanical properties of palm oil clinker concrete. Paper presented at the $1^{\text {st }}$ Engineering Conference on Energy and Environment. 27-28 December 2007, Kuching, Sarawak.

Ahmmad, R; Alengaram, U J; Jumaat, M Z; Sulong, N H R; Yusuf, M O and Rehman, M A (2017). Feasibility study on the use of high volume palm oil clinker waste in environmental friendly lightweight concrete. Construction and Building Materials, 135: 94103.

Akan, M O A; Dhavale, D G and Sarkis, J (2017). Greenhouse gas emissions in the construction industry: An analysis and evaluation of a concrete supply chain. J. Cleaner Production, 167: 1195-1207.

Alengaram, U J; Mahmud, $\mathrm{H}$ and Jumaat, $\mathrm{M} \mathrm{Z}$ (2011). Enhancement and prediction of modulus of elasticity of palm kernel shell concrete. Materials and Design, 32: 2143-2148.

Alengaram, U J; Mohottige, N H W; Wu, C; Jumaat, M Z; Poh, Y S and Wang, Z (2016). Response of oil palm shell concrete slabs subjected to quasi-static and blast loads. Construction and Building Materials, 116: 391-402.

Allacker, K; De Souza, D M and Sala, S (2014). Land use impact assessment in the construction sector: An analysis of LCIA models and case study application. The Int. J. Life Cycle Assessment, 19: 1799-1809.

Anton, L A and Diaz, J (2014). Integration of LCA and BIM for sustainable construction. Int. J. Social, Education, Economics and Management Engineering, 8: 1356-1360.

Aslam, M; Shafigh, P and Jumaat, M Z (2016). Oilpalm by-products as lightweight aggregate in 
concrete mixture: A review. J. Cleaner Production, 126: 56-73.

Barcelos, E; Rios Sde, A; Cunha, R N; Lopes, R; Motoike, S Y; Babiychuk, E; Skirycz, A and Kushnir, $S$ (2015). Oil palm natural diversity and the potential for yield improvement. Frontiers in Plant Science, 6: 190.

Black, L (2016). Low clinker cement as a sustainable construction material. Sustainability of Construction Materials (Khatib, J M ed.). Woodhouse Publishing, Duxford. p. 415-457.

Braga, A M; Silvestre, J D and De Brito, J (2017). Compared environmental and economic impact from cradle to gate of concrete with natural and recycled coarse aggregates. J. Cleaner Production, 162: 529-543.

Chen, C; Habert, G; Bouzidi, Y; Jullien, A and Ventura, A (2010). LCA allocation procedure used as an incitative method for waste recycling: An application to mineral additions in concrete. Resources, Conservation and Recycling, 54: 1231-1240.

Chiew, Y L and Shimada, S (2013). Current state and environmental impact assessment for utilizing oil palm empty fruit bunches for fuel, fiber and fertilizer - A case study of Malaysia. Biomass and Bioenergy, 51: 109-124.

Cohen, J (1992). A power primer. Psychological Bulletin, 112: 155-159.

Dalil, M; Amodu, I O; Abbas, Y A and Husaini, A (2017). Effect of cement factory on land use-land cover in Obajana Lokoja local government area, Kogi State, Nigeria. African J. Environmental Science and Technology, 11: 384-392.

Darras, K F A; Corre, M D; Formaglio, G; Tjoa, A; Potapov, A; Brambach, F; Sibhatu, K T; Grass, I; Rubiano, A A; Buchori, D; Drescher, J; Fardiansah, R; Hölscher, D; Irawan, B; Kneib, T; Krashevska, V; Krause, A; Kreft, H; Li, K; Maraun, M; Polle, A; Ryadin, A R; Rembold, K; Stiegler, C; Scheu, S; Tarigan, S; Valdés-Uribe, A; Yadi, S; Tscharntke, T and Veldkamp, E (2019). Reducing fertilizer and avoiding herbicides in oil palm plantations Ecological and economic valuations. Frontiers in Forests and Global Change, 2: 65.

De Vries, S C; Van De Ven, G W; Van Ittersum, M K and Giller, K E (2010). Resource use efficiency and environmental performance of nine major biofuel crops, processed by first-generation conversion techniques. Biomass Bioenergy, 34: 588-601.
Dobbelaere, G; De Brito, J and Evangelista, L (2016). Definition of an equivalent functional unit for structural concrete incorporating recycled aggregates. Engineering Structures, 122: 196-208.

Estanqueiro, B; Silvestre, J D; De Brito, J and Pinheiro, M D (2016). Environmental life cycle assessment of coarse natural and recycled aggregates for concrete. European J. Environmental and Civil Engineering, 22: 429-449.

European Union (2008). Directive 2008/98/EC of the European Parliament and of the council on waste and repealing certain directives. Official J. European Union, L312: 3-30.

Germer, J and Sauerborn, J (2008). Estimation of the impact of oil palm plantation establishment on greenhouse gas balance. Environment, Development and Sustainability, 10: 697-716.

Grbeš, A (2015). A life cycle assessment of silica sand: Comparing the beneficiation processes. Sustainability, 8: 11.

Hamada, H M; Jokhio, G A; Yahaya, F M; Humada, A M and Gul, Y (2018). The present state of the use of palm oil fuel ash (POFA) in concrete. Construction and Building Materials, 175: 26-40.

Hamid, W A and Rahman, S B W A (2016). Comparison results of forest cover mapping of Peninsular Malaysia using geospatial technology. IOP Conference Series: Earth and Environmental Science, 37: 012027.

Hansen, S B; Olsen, S I and Ujang, Z (2014). Carbon balance impacts of land use changes related to the life cycle of Malaysian palm oil-derived biodiesel. Int. J. Life Cycle Assessment, 19: 558-566.

Hansen, S B; Padfield, R; Syayuti, K; Evers, S; Zakariah, Z and Mastura, S (2015). Trends in global palm oil sustainability research. J. Cleaner Production, 100: 140-149.

Hashim, Z; Subramaniam, V; Harun, M H and Kamarudin, N (2018). Carbon footprint of oil palm planted on peat in Malaysia. Int. J. Life Cycle Assessment, 23: 1201-1217.

Huijbregts, M A J; Steinmann, Z J N; Elshout, P M F; Stam, G; Verones, F; Vieira, M D M; Hollander, A; Zijp, $M$ and Van Zelm, R (2016). ReCiPe 2016: A Harmonized Life Cycle Impact Assessment Method at Midpoint and Endpoint Level. National Institute for Public Health and the Environment. 194 pp. 
Hosseinian, S M and Nezamoleslami, R (2018). Water footprint and virtual water assessment in cement industry: A case study in Iran. J. Cleaner Production, 172: 2454-2463.

ISO (2006a). Environmental management - Life cycle assessment - Principles and framework (ISO Standard No. 14040:2006). https:/ / www.iso.org/ standard/37456.html, accessed on 1 December 2019.

ISO (2006b). Environmental management - Life cycle assessment - Requirements and guidelines (ISO Standard No. 14044:2006). https:/ / www.iso. org/standard/38498.html, accessed on 1 December 2019.

Kanadasan, J and Abdul Razak, H (2015a). Engineering and sustainability performance of self-compacting palm oil mill incinerated waste concrete. J. Cleaner Production, 89: 78-86.

Kanadasan, J and Abdul Razak, H (2015b). Utilization of palm oil clinker as cement replacement material. Materials, 8: 8817-8838.

Kanadasan, J; Ahmad Fauzi, A F; Abdul Razak, H; Selliah, P; Subramaniam, V and Yusoff, S (2015). Feasibility studies of palm oil mill waste aggregates for the construction industry. Materials, 8: 6508-6530.

Karim, M R; Khandaker, M U; Asaduzzaman, K; Razak, H A and Yusoff, S B (2018). Radiological risks assessment of building materials ingredients: Palm oil clinker and fuel ash. Indoor and Built Environment, 28: 479-491.

Kim, T; Tae, S and Chae, C (2016). Analysis of environmental impact for concrete using LCA by varying the recycling components, the compressive strength and the admixture material mixing. Sustainability, 8: 389.

Kongsager, R and Reenberg, A (2012). Contemporary Land-use Transitions: The Global Oil Palm Expansion. Copenhagen, GLP International Project Office. 45 pp.

Kurda, R; Silvestre, J D and De Brito, J (2018). Life cycle assessment of concrete made with high volume of recycled concrete aggregates and fly ash. Resources, Conservation and Recycling, 139: 407-417.

Landfield, A H and Karra, V (2000). Life cycle assessment of a rock crusher. Resources, Conservation and Recycling, 28: 207-217.

Marinkovic, S; Dragas, J; Ignjatovic, I and Tosic, N (2017). Environmental assessment of green concretes for structural use. J. Cleaner Production, 154: 633-649.
Marinkovic, S; Habert, G; Ignjatovic, I; Dragas, J; Tosic, N and Brumaud, C (2016). Life cycle analysis of recycled aggregate concrete with fly ash as partial cement replacement. Paper presented at the Sustainable Built Environment (SBE) Regional Conference. 15-17 June 2016.

Marinkovic, S; Radonjanin, V; Malesev, M and Ignjatovic, I (2010). Comparative environmental assessment of natural and recycled aggregate concrete. Waste Management, 30: 2255-2264.

Martínez-Rocamora, A; Solís-Guzmán, J and Marrero, M (2016). LCA databases focused on construction materials - A review. Renewable and Sustainable Energy Reviews, 58: 565-573.

Mazlan, D; Krishnan, S; Din, M F M; Tokoro, C; Khalid, N H A; Ibrahim, I S and Komori, D (2020). Effect of cellulose nanocrystals extracted from oil palm empty fruit bunch as green admixture for mortar. Scientific Reports, 10: 6412.

Mo, K H; Visintin, P; Alengaram, U J and Jumaat, M Z (2016). Prediction of the structural behaviour of oil palm shell lightweight concrete beams. Construction and Building Materials, 102: 722-732.

Mohammadi, J and South, W (2017). Life cycle assessment (LCA) of benchmark concrete products in Australia. The Int. J. Life Cycle Assessment, 22: 15881608.

Mohd Hilton, A; Lee, Y L and Nurazuwa, M N (2008). Water permeability of Malaysian palm oil clinker concrete. Paper presented at the Malaysian Technical Universities Conference on Engineering and Technology. 8-10 March 2008.

MPOB (2015). Malaysian Oil Palm Statistics 2015. MPOB, Bangi. 210 pp.

MPOB (2020). Overview of the Malaysian palm oil industry 2019. http:/ / bepi.mpob.gov.my/images / overview / Overview_of_Industry_2019.pdf, accessed on 3 June 2020.

Muhammad-Muaz, A and Marlia, M H (2014). Water footprint assessment of oil palm in Malaysia: A preliminary study. AIP Conference Proceedings, 1614: 803-807.

Murphy, D J (2014). The future of oil palm as a major global crop: Opportunities and challenges. J. Oil Palm Res. Vol. 26: 1-24.

Mutert, E; Fairhurst, T H and von Uexküll, H R (1999). Agronomic management of oil palms on deep peat. Better Crops International, 13: 22-27. 
MY-LCID (2020). Malaysia Life Cycle Inventory Database. $\quad$ http://mylcid.sirim.my/sirimlca/, accessed on 20 May 2020.

Nambiappan, B; Ismail, A; Hashim, N; Ismail, N; Shahari, D N; Idris, N A N; Omar, N; Salleh, K M; Hassan, N A M and Kushairi, A (2018). Malaysia: 100 years of resilient palm oil economic performance. J. Oil Palm Res. Vol. 30(2): 13-25.

Nemecek, T; Knuchel, R F; Alig, M and Gaillard, G (2010). The advantages of generic LCA tools for agriculture: Examples SALSAcrop and SALCAfarm. Paper presented at the $7^{\text {th }}$ International Conference on Life Cycle Assessment in the Agri-Food Sector. 22-24 September 2010. Bari, Italy.

Onn, C C; Mo, K H; Radwan, M K H; Liew, W H; Ng, C G and Yusoff, S (2019). Strength, carbon footprint and cost considerations of mortar blends with high volume ground granulated blast furnace slag. Sustainability, 11: 7194.

Ooi, Z X; Ismail, H; Bakar, A A and Teoh, Y P (2014). A review on recycling ash derived from Elaeis guineensis by-product. Bioresources, 9: 7926-7940.

Quadry, M O; Mohamad, A and Yusof, Y (2017). On the Malaysian Ringgit exchange rate determination and recent depreciation. Int. J. Economics, Management and Accounting, 25: 1-26.

Sayer, J; Ghazoul, J; Nelson, P and Boedhihartono, A K (2012). Oil palm expansion transforms tropical landscapes and livelihoods. Global Food Security, 1: 114-119.

Rahman, Z A; Gikonyo, E W; Silek, B; Goh, K J and Soltangheisi, A (2014). Evaluation of phosphate rock sources and rate of application on oil palm yield grown on peat soils of Sarawak, Malaysia. J. Agronomy, 13: 12-22.

Safitri, L; Hermantoro, H; Purboseno, S; Kautsar, V; Saptomo, S and Kurniawan, A (2018). Water footprint and crop water usage of oil palm (Elaeis guineensis) in Central Kalimantan: Environmental sustainability indicators for different crop age and soil conditions. Water, 11: 35.

Said, N; Ahmad, S M S; Malar, V S; Syafiqah, A K; Hajar, A M S and Aina, A R (2016). Precious nickel recovery from palm oil mill fuel ash waste $(\mathrm{Ni}-$ POMFAW) using acidic leaching extraction (ALE). Key Engineering Materials, 705: 374-379.

Salleh, S F; Abd Rahman, A and Tuan Abdullah, T A $R$ (2018). Potential of deploying empty fruit bunch (EFB) for biomass cofiring in Malaysia's largest coal power plant. Paper presented at the $7^{\text {th }}$ International Conference on Power and Energy. 3-4 December 2018.

Shafigh, P; Mahmud, H B; Jumaat, M Z and Zargar, M (2014). Agricultural wastes as aggregate in concrete mixtures - A review. Construction and Building Materials, 53: 110-117.

Shiffler, R E (1988). Maximum Z scores and outliers. The American Statistician, 42: 79-80.

Shin, Y-S and Cho, K (2015). BIM application to select appropriate design alternative with consideration of LCA and LCCA. Mathematical Problems in Engineering, 2015: 281640.

Sims and Brown (1998). Concrete aggregates. Lea's Chemistry of Cement and Concrete (Hewlet, P C ed.). Butterworth-Heinemann, Oxford. p. 9071015.

Subramaniam, V; Choo, Y M; Muhammad, H; Hashim, Z; Yew, A T and Puah, C W (2010). Life cycle assessment of the production of crude palm kernel oil (Part 3a). J. Oil Palm Res. Vol. 22: 904-912.

Subramaniam, V and Hashim, Z (2018). Charting the water footprint for Malaysian crude palm oil. J. Cleaner Production, 178: 675-687.

Subramaniam, V; Ma, A N; Choo, Y M and Nik Meriam, N S (2008). Life cycle inventory of the production of crude palm oil - A gate to gate case study of 12 palm oil mills. J. Oil Palm Res. Vol. 20: 484-494.

Sumesh, M; Alengaram, U J and Nayaka, R R (2018). Effect of binder content and water-binder ratio in mortar developed using partial replacement of cement with palm oil clinker powder. IOP Conference Series: Materials Science and Engineering, 431: 082007.

Suttayakul, P; Aran, H K; Suksaroj, C; Mungkalasiri, J; Wisansuwannakorn, R and Musikavong, C (2016). Water footprints of products of oil palm plantations and palm oil mills in Thailand. Science of the Total Environment, 542: 521-529.

Tait, M W and Cheung, W M (2016). A comparative cradle-to-gate life cycle assessment of three concrete mix designs. The Int. J. Life Cycle Assessment, 21: 847860.

Tay, J H (1990). Ash from oil-palm waste as concrete material. J. Materials in Civil Engineering, 2: 94-105. 
Tosic, N; Marinkovic, S; Dasic, T and Stanic, M (2015). Multicriteria optimization of natural and recycled aggregate concrete for structural use. J. Cleaner Production, 87: 766-776.

Van den Heede, P and De Belie, N (2012). Environmental impact and life cycle assessment (LCA) of traditional and 'green' concretes: Literature review and theoretical calculations. Cement and Concrete Composites, 34: 431-442.

Van den Heede, P and De Belie, N (2014). A service life based global warming potential for high-volume fly ash concrete exposed to carbonation. Construction and Building Materials, 55: 183-193.
Veraart, F (2018). Building materials and construction: Sustainability, dependency and foreign suppliers. Well-being, Sustainability and Social Development: The Netherlands 1850-2050 (Lintsen, H; Veraart, F; Smits, J-P and Grin, J eds.). Springer, Cham. p. 417-434.

Zambelli, B and Ciurli, S (2013). Nickel and human health. Metal Ions in Life Sciences, 13: 321-357.

Zarcinas, B A; Ishak, C F; McLaughlin, M J and Cozens, G (2004). Heavy metals in soils and crops in southeast Asia. 1. Peninsular Malaysia. Environmental Geochemistry and Health, 26: 343-357. 